Mediterranean Journal of Humanities mjh.akdeniz.edu.tr II/1, 2012, 61-86

\title{
On the Tradition of Islamic Figural Sculpture to 1300
}

\author{
14. yüzyıla kadarki İslami Figüratif Heykeltraşlık Geleneği Üzerine
}

\section{T. M. P. DUGGAN*}

\begin{abstract}
This article outlines the tradition of Islamic figural sculpture from the early $8^{\text {th }}$ c. to 1300 , citing both surviving examples and the record of those many examples that no longer survive from areas as diverse as Syria-Palestine, Iraq, N. Africa, Afghanistan, Iran, Andalusia and Anatolia, in relief and in the round, figurines and larger sculptures in a variety of materials. Attention is drawn to the 'statue of the lancer figure' that was placed on top of al-Qubbah al-Khadra, the hall of audience of the Caliph, Abu Ja'far al Mansur, in Bagdad and which remained in-situ until 941 and which was recorded by Ibrahim b. 'Ali al-Khutabi in the $10^{\text {th }} \mathrm{c}$. as, 'the crown of Bagdad, a guidepost for the region and one of the great achievements of the Abbasids'. A clearly visible landmark sculpture and a Caliphal model for Islamic rulers in the use in public, as well as in private spaces, of sculpture.
\end{abstract}

Keywords: Early Islamic Sculpture, Reliefs, Abbasid automata

Özet: Bu makale, erken VIII. yüzyıldan XII. yüzyılın sonlarına değin İslami figüratif heykeltıraşlık geleneğini antik kaynaklar ışığında inceleyerek, Suriye-Filistin, Irak, Kuzey Afrika, Afganistan, İran, Endülüs ve Anadolu gibi farklı coğrafyalardan günümüze ulaşabilmeyi başaran ya da kayıtlara geçen örnekler ışığında ele almaktadır. Özellikle Bağdat’ta halife Abu Ja-far al Mansur’un kabul salonunu örten al-Qubbah al Khadra'nın (Yeşil Kubbe) tepesine konuşlandırılan ve X. yüzyılda yaşayan İbrahim bin Ali al-Khutabi tarafından “Bağdat'ın tacı, bölgenin sembolü ve Abbasilerin gerçekleştirdiği en önemli eserlerden biri” olarak kabul edilen 'atlı mızraklı süvari' 941 yılına kadar yerinde in-situ şeklinde durmuştur. Bu yönüyle İslami yöneticilerin halife örneğinde de izlenebildiği üzere, kamu alanlarında olduğu kadar özel alanlarda da halk tarafından görülebilen nirengi noktalarında heykellerinin yer aldığı iddia edilmektedir.

Anahtar Kelimeler: Erken İslamik Heykeller, Kabartmalar, Abbasi haraketli heykelleri

This article surveys some of the considerable evidence for the production of works of figural sculpture in the Islamic world, citing examples from Syria-Palestine, Iraq, Iran, Anatolia and Andalusia, in the period from the late $7^{\text {th }}$ c. to 1300 ; given the change in attitute towards figural

\footnotetext{
* Sanat Tarihçi, Akdeniz Üniversitesi, Akdeniz Uygarlıkları Araştırma Enstitüsü, Antalya, tmpduggan@yahoo.com Without the assistance of A. Akçay, \& Ç. A. Aygün in providing the computer graphic reconstructions, a time consuming work, this article would be the poorer, as these engineering manuscript illuminations needed to be seen stripped of text and markers so that these works of sculpture can be clearly apprehended for what they were, works of Islamic sculpture. Further, is there a marked difference in sculptural qualities between a larger than life-sized work of, for example, Hellenistic sculpture and a small scale Hellenistic figurine, such as a Tanagra terracotta figure? I think not. Then, as there appears to be no necessarily significant distinction to made in sculptural qualities between smaller and larger sized works of sculpture, I think it is reasonable to think the sculptural figurines recorded by alJaziri can be understood to represent the sculptural qualities of life-sized and smaller works of late $12^{\text {th }} \mathrm{c}$. figural sculpture that no longer survive today.
} 
sculpture, particularly on public buildings, following the calamity of the Mongol invasions. It is unclear if there is a causal relationship between military defeat, territorial loss, and occupation and the cessation of the production of figural sculpture in the Islamic world. It is widely understood that religious rulings and public/state practise have not been synonomous, and the opposition to images, sculpture or pictorial has varied over the various regions of the Islamic world over time. Although it seems reasonable to think that the Umayyed and Abbasid Caliphates, in their employment of figural sculpture provided a significant model in this respect.

It is a commonplace truism and it has been repeatedly said that there were no Islamic sculptures made of people or other living things that cast a shadow (Based primarily upon ahadith (plural of hadith) concerning this matter, see for example those provided in: Şekerci, 1974, 20-57; Yakutcan, \& Ömür, 1989, 2-12; Issa, 1996, 16-29. A troubling fact in this respect, pointed out by Creswell half a century ago, is the degree of hostility to images brought into Islam by early influential Jewish converts, the Isra’iliyat, including: the Yemenite Jew Ka’b alAhbar (d. 652), who converted to Islam in 638, 'Abd Allah ibn Abbas (619-687), Abu Huraira and Wahb ibn Munabbih (655-732), bringing an opposition to images which, it is suggested, in part originated in ahadith concerning images that were transmitted by these Jewish converts to Islam, Creswell, 1958, 98; Arnold 1965, 10. As this seems to have been the case, a somewhat bizarre situation has existed since the end of the $7^{\text {th }}$ c. in respect to figural images, painted or sculpted, in the Islamic world, where Muslim sculptures and paintings are defaced or destroyed by fellow Muslims, in actions justified on the basis of Jewish attitudes towards figural images in ahadith transmitted by $7^{\text {th }}$ c. Jewish converts into Islam. An example being the hadith transmitted by Abu Huraira, "He commanded to lop off the head of the statue so that it becomes like the form of a tree." in respect to the Prophet giving orders to his son in law Ali, concerning the destruction of an idol, not in fact referring to any ordinary statue, but to an idol; but which was subsequently applied to justify defacing any sculpture depicting a human head. These ahadith have been judged sound by the most eminent of religious scholars and compilers of hadith literature - that is, there was a chain of living known trustworthy persons who passed on these traditions-ahadith which were said to have been uttered by the Prophet from Muslim to Muslim until they were transcribed in the $9^{\text {th }}$ c., and God knows best the truth of this).

Writing of Islamic painting half a century ago, and which still remains the case today for Islamic figural painting, and which is even more so in the case of Islamic sculpture, K. A. C. Creswell wrote, "Even at the present day the belief is very widely held that all forms of painting are forbidden by explicit passages in the Quran, but this is a popular error for no such passages exist" (Creswell, 1958, 97); nor do any such passages exist in the Holy Koran forbidding the making of statues. What is of course explicitly forbidden is idolatry, and the making or use of idols, in whatever material, form or nature any such idols are given or possess. An idol is not necessarily a statue, and a statue is of course, not necessarily an idol.

However, regarding the statement that there were no Islamic sculptures made of people or other living things that cast a shadow, this is quite simply not true. There stood for nearly 200 years at the very centre of the Abbasid Caliphate, on top of the domed roof above the Caliph's audience chamber in the capital, Madinat as-Salam - Bagdad, at the time when the Abbasid Caliphate reached the summit of its power and extent, a famous gilded metal statue of a lancer on horseback which was over life-size and was visible from beyond the city walls, which was ordered placed in this position by the Caliph Abu-Ja'far al-Mansur, the founder of Bagdad (Hitti, 1991, 419; Kennedy, 2004, 136, citing Ibn abi-Usaybi'ah, vol. II, 155, 163). It was made, gilded and was erected in this unrivalled position overlooking the capital, and it seems evident that this sculpture symbolised al-Mansur's watchfulness and jihad, against schismatics, against idolaters, as at Kandarhar where the idol was destroyed, and against the East Romans, and may 
have depicted, or was understood to portray the Caliph himself and came to symbolise the Caliphate itself. The horseman on the Green Dome was famous and this work of sculpture was described in the $10^{\text {th }}$ c. as, "the crown of Baghdad, a guidepost for the region and one of the great achievements of the Abbasids"' (Kennedy, 2004, 136, n. 12, citing Ibrahim b. 'Ali alKhutabi (d. 340/951). It is worth repeating and reflecting on this $10^{\text {th }}$ c. statement made by a Muslim - that a gilded metal sculpture of a lancer on horseback raised upon the top of a dome was regarded by contemporaries as being the crown of Bagdad, that this sculpture served as a marker for the region, and that this work of sculpture was regarded in the $10^{\text {th }} \mathrm{c}$. as one of the great achievements of the Abbasid Caliphate, and that this sculpture was recorded as such.

The reasons for the repeated denial of the existence of this sculptural tradition both in the Islamic world and in the past in West, as is frequently the case today, are several; including, but not exclusively made by persons who are entirely unaware of the existence of this tradition. However, the inescapable fact remains that Islamic rulers, some renowned for their faith and including amongst their number, both Umayyad and Abbasid Caliphs, commissioned over the course of more than half a millennia both relief sculptures and sculptures fashioned in the round of humans, male and female, animals, birds and other creatures. At the time when these sculptures were made, it was clearly understood by both ruler and populace that these sculptures were not idols made to be worshipped - idolatry in its varied forms is explicitly and repeatedly forbidden in the Holy Koran as the one sin that the Almighty will not forgive, Sura 4, Al-Nisa, 116; and that "Idolatry is worse than carnage", Sura Al-Baqarah, 2: 191-4; also Sura Al-Ahqaf, 46: 5; Sura Al-Nahl, 16: 20-21 and 73; and Sura Al-A'raf, 7: 190-200)- but these were works of sculpture, works of art, man-made signs, symbols, carrying a particular meaning or series of meanings, reminders and associations to Muslims, and these sculptures formed an integral part of the expression of ruler-ship and were a sometimes remarked upon, commonplace part of the visible world for city dwellers in the Islamic world. These sculptures were also at times recorded and remarked upon by interested travellers, both Muslim and Christian, over the course of the centuries, not just in Bagdad but in cities from Granada to Ghazna and Konya to Cairo. In part, it seems, these Islamic sculptures were legitimised by the precedent and example provided by the Prophet - ruler Süleyman bin Daud (Solomon) and the jinn who worked under his command, making amongst other things, statues, not idols, for him (Holy Koran, Sura Saba, 34: 13).

There are many surviving examples of Islamic sculptures of people and of other living things, carved in relief and also in the round, both statuettes and sculptures, some life-sized and larger, surviving, if often beheaded or broken into pieces by past and present zealots, that date from the late $7^{\text {th }}$ c. onwards which have been excavated, often illegally, and are preserved today in numerous museums and private collections; while there is clear record of no longer surviving Islamic figural sculptures preserved in Islamic, as in Greek, as also in Latin Christian medieval sources (where they are often described as "idols", See Daniel, 1979, 238-39, and references provided in the notes to these pages. For example, in the $12^{\text {th }}$ century famous poem the "Chanson de Roland", said to describe Emperor Charlemagne's expedition against the Spanish Moslems of 778 AD. there are the following lines: "The Emperor has captured Sargossa and has the town searched by a thousand of his Franks. In the Synagogues and temples of Muhammed (Mosques), with iron clubs and hand axes, they smash Muhammed and all the other idols so that no devilry or superstition will remain...His (Charlemagne's) Bishops bless the waters and lead the pagans (Moslems and Jews) to the Baptistery. If one of them opposes the will of Charles, then he has him imprisoned, burnt or slain. More than 100,000 are thus baptized, made true Christians". A position entirely distinct and antithetical to that taken by figures such as William Durand c. 1220-1296, called "the speculator" for his spirit of enquiry, a nobleman of Languedoc and 
Professor of cannon law at Modena, who in his Rationale Divinorum Officiorum Book 1, writes: But Paynim (Pagans) adore images, as icons, and idols; which Saracens (Muslims) do not, who neither will possess nor look on images, grounding themselves on that saying, "Thou shalt not make to thyself any graven image, nor the likeness of any-thing that is in heaven or earth beneath, nor in the waters under the earth," and on the other like authorities; these they follow incontinently, casting the same in our teeth....So also the Prophet, "Their idols are silver and gold, the work of man's hand. They that make them are like unto them: and so are all they put their trust in them." And again: "Confounded be all that they worship graven images; and that put their glory in their idols." Holt, 1957, 121-2, who thus clearly states for the $13^{\text {th }} \mathrm{c}$. literate Christian that the Muslims' possessed no images. Sic et non, yes or no, in modern parlance, your either with us or against us, it was this unequivocal reductionism which meant that the very idea that there were statues in Muslim territory, that were commissioned and that were made by Muslims but which were not worshipped by Muslims seems to have been so exceedingly difficult an idea to be grasped by Medieval Latin Christians (as also by some Muslims of today) who state either, that they had them, based upon report of these statues, and therefore, that they worshipped them, or, that they did not have them, basing their opinion upon anti-figural hadith and Islamic religious texts and reports of those texts incorporating this material and, in consequence, denying all report of the physical fact, the historical reality of Islamic sculpture.

The idea that all objects such as statues, man-made or natural, such as rock outcrops, looking like people or creatures, that are, or have been the subject of notice, attention and of worship, of idolatry, should be smashed, defaced or destroyed is a recipe for the destruction of the human race and this planet. What is of course to be uprooted is idolatry in the heart, this uprooting of idolatry is the essence of Oneness or Unity, Holy Koran Sura At-Tauhid, The Unity, 112: "Say: He is Allah, the One! Allah, the eternally besought of all! He begatteth not nor was begotten. And there is none comparable unto Him."; as for example in the $13^{\text {th }} \mathrm{c}$. when speaking to Jelal-ad Din Rumi (1207-73): “The Na'ib said: Before this, the unbelievers used to worship and bow down to idols. We are doing the self-same thing in the present time. We go and bow down and wait upon the Mongols, and yet we consider ourselves Muslims” Arberry, 1977, 89.

The distinction between man's forming of an object and the Almighty's creative actions is clearly stated in the Holy Koran, Sura 5, Al-Ma'idah, 110, where the Prophet İsa (Jesus) shapes a bird from clay, but it only flies when the Spirit is breathed into it, clearly distinguishing between the Almighty, who both forms and gives Spirit, as with the Creation and the making of Adam, and a simple forming of the outward appearance, in a sculpture made from clay or from any other material. Jelalad-Din Rumi similarly remarks upon this fundamental distinction, "The painting on the wall is like Adam; see from that (pictured) form what is wanting," Mathavi 1982, Book. 1, verse 1020, that which is lacking being the Spirit as distinct from the "surat", the form. Consequently, it seems to this author that those who assert that sculptors, engineers or painters were, or are, in their activities competing with, or imitating, the actions of the Creator, thereby exhibit a remarkable lack of discrimination in failing to distinguish between a form infused with the Spirit and an image or a sculpture, an empty material form which may be mobile, may even utter sounds, but lacks the Spirit, and, as such, these accusers would seem to be guilty of shirk, that is of associating partners, forms, with the Divine-that is to have confused the Real with that which is conditional upon it). This, in addition to the re-use, and at times the conversion through re-carving or otherwise altering antique and East Roman sculpture, often placed in the face of walls and fortifications of Muslim ruled cities, as in the city walls of Rum Seljuk Konya reconstructed in 1221 (See for example the plate depicting the Roman statue of Hercules and ancient reliefs in the walls of Konya published in Laborde, 1839, 
Pl. LXIV, 133), and which, like the antique sculptures surviving in East Roman Constantinople, were frequently said to have served a talismanic function (For example. Irwin, 1997, 211, attributes a talismanic function to the twice life-size Roman statue of Hercules placed on the exterior of this Konya gate; and this is also recorded for the ancient sculpture of a lion built into the Seljuk walls of Hamadan, reportedly by the Prophet Solomon-Sülayman, and which was said to possess a talismanic function as Ibn al-Faqi relates. However, it may well be that the appearance of some of the re-employed ancient works of sculpture were altered, not only through re-carving but through the application of stucco, to provide a different more culturally relevant meaning to these works, but, through the passage of time the stucco additions fell off, and then the talismanic function came to the fore, to account for the presence of these pagan sculptures within Islamic structures (for further on this matter see, Duggan, 2011, 150-51, 154-8); or, for example the Hindu temple figural sculptures which were taken from destroyed Indian temples to Ghazna in Afghanistan, and which were deliberately re-used in the remodelling of the Ghaznavid palace in the $11^{\text {th }}$ c. by Sultan Mu'sud I (1030-41), together with human figural sculpture in the round, in bronze, stucco and marble, a feature both of Mahmud and of Mu'sud's palaces at Ghazna (Rugiadi, Fig. 5; Bosworth, 1973, 135-6, 140). Today, on the basis of both recent and previously excavated finds, which confirm the references made to these sculptures and statues in both Muslim and other historical sources, no basis whatsoever remains, apart from ignorance and bigotry, for the assertion that in the Islamic world in the past there were no sculptures made of human or other figures that cast a shadow, and that there was no tradition of sculpture in the Islamic world. There most certainly was, and significant physical, literary and visual evidence of this tradition survives today.

These statues, relief sculptures and statuettes, portraying people, animals and birds, were not only made for the private interior of palaces, but also for public display on the exterior facade of palaces, and on city gates and towers and domes, on bridges, and on the facades of other public buildings, including those founded and maintained through religious foundations, vakif; as also sometimes forming an important part of major public clepsydra-water-clocks, such as that displayed on the Jayrun Gate - Bab al-Jabiye of Damascus; also called the Gate of the Hours, from its water-clock constructed in 1164 and which remained working into the $14^{\text {th }}$ c., (Fig. 12) and of public and palace fountains (Such as the fountain erected by 'Abd al-Rahman III (91261) in the Palace at Madinat az-Zahra by Cordoba which had a marble basin carved with human figures brought from Constantinople, he was allied with the East Romans against the Abbasids, and then added to this basin were 12(sic) creatures of gold with pearls applied made in Cordoba, a lion with a gazelle beside it, a crocodile, a serpent, an eagle, an elephant, a dove, a falcon, a peacock, a hen, a cock, a hawk and a vulture and from their mouths spouted water, Arnold, 1965, 23, citing Makkari). While statuettes depicting people, animals and birds were frequently made in a variety of materials (For glass figurines see for example: $8^{\text {th }}-9^{\text {th }}$ c. Egyptian or Syrian glass birds, Cat. $3.64 \mathrm{a}, \mathrm{b}, 9^{\text {th }}-12^{\text {th }}$ c. Cat. $79,10^{\text {th }}-11^{\text {th }}$ c. birds and animals from Iran, in, Carboni, 2001; for ceramic examples and references to comparative pieces, Cat. No. Ab. 10; Cat. Gc.7, in, Watson, 2004; while there is a $2^{\text {nd }}$ half of the $12^{\text {th }}$ c. glazed pottery camel $32.5 \mathrm{cms}$ high in the Museum für Islamische Kunst, Berlin (Inv.-Nr.77/62) and another $12^{\text {th }}$ c. camel 39.5 cms. high in the lustre technique (Irwin, 1997, 251) and a fine $13^{\text {th }}$ c. glazed horseman figurine from Raqqa, Syria, in the Nat. Mus. Damascus, and numerous human heads survive from figurines and handles, eg. Robinson, 1988, Cat. No. C3i, as also in relief on clay vessels and the vessels themselves were often shaped into the form of birds, animals and people, including bronze aquamanile and incense burners in the form of a lion, or a bird, and pottery ewers with the form of a creature, such as the cockerel, produced at Kashan in the $13^{\text {th }}$ c. Hattstein, \& Delius 2000, 383. For examples of metal figurines see M5 of a bird, M6 of a camel, and for rock crystal statuettes of a lion, R6, R5 a fish and a hare R12, Robinson, 1988). Some were imported 
by sea into Bagdad in the $9^{\text {th }}$ c., recorded by Amr ibn Bahr, al-Jahiz as, "knicknacks with human figures” (Lopez-Raymond, 1990, 28) imported from China, while some figurines, of humans, birds, animals and even a tree, were cast in sugar (Thackston, Jr. W. M, 1986, 57). Human and bird figurines are still made of fired painted clay today, represented for example by the large, although not life-size, fired clay statues and statuettes produced in Sejnan, Bizerta in Tunisia and the painted glazed figurines depicting birds in Turkey by Balikesir, and at Kütahya, as also in Syria and elsewhere, serving a symbolic function; and figurines were also produced as toys made for children, like the dolls described by A'ishah to the Prophet as, "the horses of Solomon" (Arnold, 1965, 7), small figurines of winged horses. Repeatedly, in low relief, the depictions of human figures and creatures were cast and they were also incised and inlaid in metal vessels, they were also carved in stone, in wood and in ivory and cast and carved in stucco-plaster, they were also depicted in carved and cast glass, carved in rock crystal, and figurines were also cast in gold as jewellery (Hattstein, \& Delius, 2000, 242). Statuettes of human figures and creatures were modelled in clay and cast in brass and bronze; while low relief depictions of human figures and human faces were struck on medallions and seals, including for example, the earliest surviving naturalistic profile portrait made of any Islamic ruler, struck on the seal of Sultan Alaed-Din Keykubat 1 (1219-37) found in 2000 (Duggan, 2007), seated lion on reverse, and today on display in the Antalya Museum; and depictions of human figures and creatures in low relief were struck on the currency of some Islamic states in the past, in the $7^{\text {th }}$ century (Issa, 1996, 30-31. For examples of the fals of the standing Caliph with "kalima", see: Falk, 1985, Nos. 377, 378, 379; Artuk-Artuk, 1971, Cat. No.9-13; Sourdel, 1968, ill. 23, has perhaps the finest illustration of this Caliph on a coin. The dinar carrying the "kalima" is illustrated in Irwin, 1997, figs. 70, 88-89; Falk, 1985, Cat. No. 368, and is otherwise a copy of the figures on the 50 solidus of the East Roman Emperor Heraclius (610-41)) struck within the lifetime of the Companions of the Prophet, as also during the $12^{\text {th }}$ and $13^{\text {th }}$ centuries in Anatolia (For numerous examples see: Bartur, 1994 Seljuk; Bartur, 1994 Beylik, Cat. Nos. 1-30; Falk 1985, Cat. Nos. 517-536), as is the case for some Islamic and Muslim majority states today, such as the bird of prey, a falcon, printed on the banknotes of the UAE, and the portrait of Gazi Mustafa Kemal Atatürk on the Turkish Lira. However, the peak of the Islamic sculptors' art in the portrayal of human and other figures was reached in the sometimes life-sized metal sculptures of human and other figures, which were gilded and decorated, and sometimes dressed in expensive fabrics, that moved and sometimes spoke, these were the automata, deployed in public spaces as public sculptures forming a noteworthy part of water-clocks, as also of other sculptural works within the audience chambers of rulers and viziers and at private gatherings (Figs. 12-15) (For some examples in addition to those given below, see, Duggan, 2009, 229 - 267). These were sculptures that amazed, through their life-like appearance, the motion given to them and the sounds-speech they appeared to make. The depiction of humans and creatures in high and low relief and in free-standing sculptures, some of which both moved and spoke, made by Muslim artists for Muslim rulers, seems in fact to have been an entirely unexceptional practice for more than half a millennia after the Hijra of 622.

\section{Under the Umayyads}

The desert palaces constructed by the Umayyads in the late $7^{\text {th }}$ and $8^{\text {th }}$ c. in Palestine, Jordan and Syria contained not only paintings depicting animals and people, including guards and rulers at Qasr Amra, Jordan; and mosaic and sculpted depictions of animals in relief (Fig. 1) and lions carved in the round (Fig. 2) but also life sized male and female statues as at Mshatta, Jordan, built for the Caliph al-Walid II (743-4); as well as heads of people carved in stucco-plaster in high relief, a stucco statuette of a guardsman and life-size sculptures including statues of concubines (Fig. 3) and one depicting a standing Caliph, probably to be identified with Marwan 
II (744-50) which survive today from Khirbat al-Mafjar, Palestine (Ettinghausen-Graber, 1994, 56-71, Figs. 28, 35- 38, 44; Hattstein, \& Delius, 2000, 81-87) (Fig. 4) and the sculptures of two princes from Qasr al-Hayr (West), Syria (Illustrated in, Ettinghausen-Graber, 1994, Figs. 30, 31). These works of sculpture can be seen today in museums in Damascus, in the Museum für Islamische Kunst, Berlin, in Jordan and Jerusalem; while it is reported that the Umayyad appointed governor of Egypt also had sculptures of figures in his palace bath-house.

The Umayyad Caliph in Andalusia, 'Abd ar-Rahman III (912-61) had a life-sized sculpture made of his favourite wife Zahra and this statue was placed over the entrance gateway to his palace which was named after his favourite, begun in 936 and called Madinat al-Zahra (Arnold, 1965 24, citing Makkari (1577-1632)’s “Nafh at-Tib”) and this statue stood over this Umayyad palace gate for at least 70 years, until it was pulled down by the Berbers in 1013.

\section{Under the Abbasids}

Under the Abbasid Caliph Abu-Ja'far al-Mansur (754-75), on top of the Green Dome-Dome of Heaven (al-Qubbah al-Khadra) above his audience chamber in his palace of the Golden Gate at the centre of his newly constructed round city-palace complex of Baghdad, capital of the Caliphate, there was a large gilded metal sculpture of a horseman with a lance which was visible from beyond the walls of the city and which remained in place on the top of the dome until 941 (Hitti, 1991, citing Ibn abi-Usaybi’ah, Vol. II, 155, 163; Arnold, 1965, 20) when it was brought down in a storm (Fig. 5). This sculpture in the $13^{\text {th }}$ c., long after its destruction, was said to have moved, even to have indicated the direction of any threat to the Caliphate (Hitti, 1991, 293, but this statue may have been confused with those that were said to turn in the wind that stood over the gates to the city, see Creswell, 1958, 165 citing al- Khatib). It was this sculpture of a lancer on horseback, on top of the Green Dome $40 \mathrm{~m}$. high (80 cubits, Creswell, 1958, 179, and 1, records the cubit as $0.5 \mathrm{~m}$ ), which seems to have been the model for the lancer figure struck on a number of Islamic coins, including for example, coins minted under the Caliph al-Muqtadir (908-32), and by the Rum Seljuk Sultans: Keyhüsrev I, Süleyman Shah, Süleyman II (Fig. 6), Keykubad I and Keyhüsrev II, and it appears on some of those minted under the Ghurids of Afghanistan and during the Delhi Sultanate of Shams ad-Din Iltutmush, with this image of the Madinat as-Salam lancer statue, therefore serving as a public, officially circulated expression of loyalty to the Abbasid Caliphate, a copy of a Muslim statue circulated on Muslim coinage minted by Abbasid Caliphs, sultans and emirs over a period of 400 years.

It is recorded that the Nasrids had a similar in form, metal sculpture of a horseman on top of a tower in their palace at Granada in the $13^{\text {th }}$ c. (Mendoza, 1982, 31-2).

Raised over each of the four gilded domes 12 cubits, $6 \mathrm{~m}$. (12 cubits) high over the four main gates completed by 766-7, facing NE, NW, SE and SW, into the round city at the centre of Abbasid Bagdad there were also metal figural sculptures (Creswell, 1958, 165, citing alKhatib's description: "These halls of audience (over each of the 4 gates to the city) were each covered by a great dome 50 cubits high and gilt. Each dome was surmounted by a figure which turned in the wind."), a human figure stood over one (Hattstein, \& Delius, 2000, 96) and perhaps a bird over another, as this is recorded in several depictions of a dome over an automata by al-Jaziri, (Tekeli, Dosay, \& Unat, 2002, Res. 1.35), perhaps suggesting that sculptures representing the 4 armies of the Prophet Süleyman were employed to crown the four gates to the inner city of Bagdad, and therefore that the other two domes over the gates were surmounted by metal sculptures representing a lion or another animal, and the figure of a jinn (For the use of depictions representing the 4 armies of the Prophet Süleyman to provide the images that were painted on the palace tiles of $13^{\text {th }}$ c. Rum Seljuk Anatolia, see, Duggan, 2006, particularly 206-208).

It is recorded that life-sized statues of lions stood beside the Abbasid Caliph's throne 
(Kennedy, 2004, 147-8), like the lions by the throne of the Umayyad Caliph Walid II at Mshatta, Jordan and which are in relief on the base of the statue of the standing Caliph, Marwan II from Khirbat al-Mafjar, Palestine, following the example of the lions by the Prophet Süleyman's throne (Figs. 2, 4).

Statues of wild animals and birds could be found in the palaces in large towns at the time of the Caliph Harun al-Rashid (786-809) (Clot, 2005, 192); while there were gigantic floating sculptures on the Tigris, six large Caliphal barges, built for the parties held by the Caliph alAmin (809-13), which were shaped above the waterline to resemble a lion, an eagle, a dolphin, a horse, an elephant and a serpent (Hitti, 1991, 419; Clot, 2005,156).

The historian Abu al Hassan 'Ali al Masudi (died in Fustat, 957) recounts how in 896 a large brass statue of a Hindu Goddess, an idol, which had been brought to Baghdad as evidence of a victory over idolaters, was exhibited on certain days to the population of Baghdad, this wonder drawing large crowds. It seems evident that without the intent to worship, statues, of themselves, even idols, removed from idolaters, were neither defaced nor smashed but were instead regarded with a certain degree of interest by the population in the capital of the Abbasid Caliphate; as later was the solid gold Hindu idol which was sent to Mecca, physical proof of his jihad, by the Ghaznavid, Yamin al-Dawla Mahmud (998-1030), the first to be awarded the title al-ghazi in 1001, for his repeated jihad against the unbelievers (Hitti, 1991, 464).

The Abbasids not only had paintings of people. including depictions of dancing women in their palaces at Samarra, but also moving and some speaking statues-robot automata inside their palaces (Duggan, 2009, 235-67), including a group of 30 life-size sculptures of warriors on horseback which were dressed in silks, which moved, giving the impression to the viewer in the $10^{\text {th }}$ c. that these horsemen were fighting, 15 were placed on either side of a pool (Arnold, 1965, 20), beside the famous silver and gold tree sculpture in the dar al-shajarah, the hall of the tree, upon which metal birds perched and sang in the $10^{\text {th }}$ century. This sculptural complex, a combination of 30 metal life-sized warriors on horseback, a large metal sculpture of a palm tree with singing sculptures of birds and a pool, within the same domed space, was without doubt one of the most remarkable and impressive, complex works of sculpture to have been produced. One of these silver and gold trees was in the throne room of the Caliph al-Mutawwakil (847-61) at Samarra (Kennedy, 2004, 147-8), another of gold and silver was constructed in the dar alshajarah in the palace in Bagdad built by the Caliph al-Muqtadir (908-932) and which is recorded in both Islamic and Christian sources (Hitti, 1991, 303; Kennedy, 2004, 154, citing Khatib, Vol. 1, 100-5; Abu-al-Fida', Vol. 2, 73; Yaqut, Vol. 2, 520-1; also Hitti, 1991, 417; 419-20), as this complex work of sculpture was seen by envoys from Constantinople concerned with the ransoming of East Roman prisoners in 917:

"When the two (East Roman) envoys entered, they kissed the ground,
gave their greeting, and stopped at the place indicated by Nasr the cham-
berlain. (The Caliph) Al-Muqtadir gave out the order for the opening of the
cupola (qubbah) and the working of the tree, which came out of the ground
by means of various mechanical devices until it filled the cupola. The
fountains, gushing forth rose water and musk, were turned on, and the
figurines (tamathil) of birds perching on the tree chirped" (from Ghada
al-Hijjawa al-Qaddumi translated in, Fairchild Ruggles, 2011, 110-111).

It doubtless provided the model for its much smaller and less complex later descendant, the Golden Tree at Timur's court by Samarkand, recorded by the Castilian envoy to Timur's court, Ruy Gonzalez de Clavijo in 1404,

"Standing and set beside the table was to be noticed a golden tree that 
stimulated (resembled) an oak, and its trunk was as thick as a man's leg, while above, the branches spread to right and left, bearing leaves like oak leaves. This tree reached to the height of a man, and below, it was made as though its roots grew from a great dish that lay there. The fruit of this tree consisted in vast numbers of balas rubies, emeralds, turquoises, sapphires and common rubies with many great round pearls of wonderful orient and beauty. These were set all over the tree while numerous little birds, made of gold enamel in many colours were to be seen perching on the branches. Of these some with their wings open seemed ready to fly and some with closed wings seemed as though they had just alighted on the twigs from flight, while some appeared about to eat the fruits of the tree, and were pecking with their bills at the rubies, turquoises and other gems or at the pearls which so to speak grew from the branches" (Quoted in, Le Strange, 1928, 154).

Further, there remains today the reminder of the large works of edible sculpture that were produced at court for feasts under the Abbasids in a famous story told by the great teacher Nasred-Din Hoca (Mulla Nasrudin):

"Three thousand distinguished epicures had been invited to a feast at the Caliph's palace in Bagdad. Nasrudin, by some mistake, was amongst them. This was an annual event, and each year the main dish excelled that of the previous feast, because the Caliphal reputation for magnificence had to be sustained and excelled.

But Nasrudin had only come for the food.

After a long wait, preparatory ceremonies, singing and dancing, an enormous number of huge silver dishes were carried in. On each one, placed between five guests, was a whole roasted peacock, decorated with artificial but edible wings and beak, its plumage shining with sugary precious gems.

There was a gasp of delight from the gourmets at Nasrudin's table, as they feasted their eyes on this supreme work of creative art" (Shah 1973, 140).

There were a series of life-size wooden portrait figures carved in the likeness of the Tulunid ruler, Khumarawayh (884-96), the son of Ahmad ibn Tulun, and of his wives and of his singing girls, that lined the walls of the Golden Hall of Khumarawayh's palace at Fustat, Egypt. All of these life-sized wooden relief figures were covered in gold leaf, as were the walls of the Golden Hall and these figures were dressed in jewelled robes and wore crowns (Arnold, 1965, 24; Hitti, 1991, 454).

There were also the sculptures of lions, large yellow brass statues, standing at each of the uppermost corners of the Ghumdan Palace in San'a, Yemen, recorded by al-Hamadani in the $10^{\text {th }}$ c., as later by Yakut in the $13^{\text {th }}$ c., sculptures of lions that roared when the wind blew through the bodies of these sculptures (Contadini, Camber, \& Northover, 2002, 69 and fn. 39).

\section{The sculpted figurines depicting the Shah, the Vizier, the Fil-Elephant, etc}

Chess is not a game of chance and so is not proscribed by the Holy Koran Sura Al-Ma'idah 5: 90, "Believers, wine, games of chance, idols and divining arrows are abominations devised by Satan", and the carved statuettes of figures and animals on the chess board were not proscribed under the law and they have formed a part of the tradition of Islamic figural sculpture to the 
present day, with the game of chess and its figured pieces so common that they are frequently mentioned in Islamic literature. For example, the Great Seljuk court official, astronomer to Nizam ul-Mulk and mathematician, Omar Khayyam (1084-1131) is said to have written the quatrain (ruba'i):

\author{
"Tis all a Chequer-board of Nights and Days, \\ Where Destiny with Men for Pieces plays: \\ Hither and thither moves, and mates and slays, \\ And one by one back in the Closet lays" (Fitzgerald, 1945, No 49, 25).
}

This poem describes life as like a chess board of black and white squares, where the figurines of the pieces move, like people, in their destined manner through life to death, Mevlana JelaladDin Rumi’s “checkmate of death” (Mathnavi, 1982, Book 3, 4187).

Jelalad-Din Rumi (1207-73), in his Mathnavi, when contrasting the literalist with the aware person writes:

"He (the player) at chess said, "This is the home of the rook (the square
upon which the Roc or chariot (castle) begins the game).". "By what
way," said he (the literalist), "did the house come into his hands? Did it
buy the house or inherit it?"- Happy is he that speed towards the (real)
meaning!" (Mathnavi, 1982 Book, 2, 3627 ff).

Through Jelalad-Din Rumi's use of this analogy, both the familiarity of Rumi and his audience with chess and with chess pieces in $13^{\text {th }}$ century Konya, and also the importance of the literal and of other methods in attempting to understand a symbolic form that can be understood to have a meaning, such as a chess piece, or, for example, the statue of the lancer on the dome in Bagdad, is clearly indicated. He makes many references to the board, game and chess pieces in the Mathnavi for example: Mathnavi, 1982 Book 2, 1780, “At one step (he moves) like the rook (roc-chariot-castle) (straight) from top to bottom (of the chessboard); (at) one step he goes crossways like the fil-elephant (bishop)"; Mathnavi, 1982 Book 3, 535 "Through travel the pawn becomes a noble queen (Vizier)"; Mathnavi, 1982, Book 3, 885-6 on chess, checkmate and victory; Mathnavi, 1982 Book 3, 2849 "And checkmated that king of the spiritual chess board". In Book. 4 109, "the essence of checkmate"; 1445-7, the chess squares and pieces, and 2889-91 for the moves of chess, while 2059 mentions the Vizier (queen) in chess; Book 5, 3507, mentions chess and checkmate, 3514, the Shah playing chess, 4061, the Roc-castle and the filelephant-bishop pieces, and in verse 4064, checkmate; while Book 6 mentions the chess pieces and places in verse $2594 \mathrm{ff}$. and checkmate, verse 2764.

Chess and the chess pieces were earlier mentioned for example by Abu al-Hassan ibn alHusayn al-Masudi in the $10^{\text {th }} \mathrm{c}$, in his, "Akhbar al-Zaman" or "Meadows of Gold" concerning the role of the courtier (nadim), on chess and other sports; by the Great Seljuk Vizier Nizam alMulk (1018-1092) in his "Siyasat-Name" of 1089-91, Chapter XVII, and by Rawardi in his, "Rahat al-Sudur wa Ayat al-Surur", "The ease of hearts and moments of happiness", dedicated to the Rum Seljuk Sultan Giyathsed-Din Keyhusrev in 1205, and Muhyid-Din ibn 'Arabi (11651240) refers to chess, Elmore, 1999, 67, "I shielded the "King" (al-Shah) with the Vizier (alFirzan)". Chess pieces were carved in ebony, ivory, crystal and precious stones, often carved in the form of figurines, people and animals, and a few survive today from $8^{\text {th }}-9^{\text {th }} \mathrm{c}$. Iran (Illustrated in, Lewis 1994, 20, where the ivory fil-elephant is strangely described in the caption as a horse) and from late $9^{\text {th }}$ - early $10^{\text {th }}$ c. Egypt in rock crystal (eg, Robinson, 1988, 299), and from elsewhere in the Islamic world, as the popularity of the game spread from the Subcontinent; firstly to Persia in the $6^{\text {th }}$ c., then to Mecca under the Umayyads (Hitti, 1991, 339), then to Bagdad and elsewhere under the Abbasids. The Caliph Harun al-Rashid (786-809) is known to have played 
chess (Hitti, 1991, 339), and it was introduced from Abbasid Bagdad into Umayyad Cordoba in Andalusia after 822 by Ziryab, Abu'l Hasan ibn Nafı' (789-857).

\section{Under the Fatimids}

The Fatimids had carved stone reliefs carrying depictions of people, some of which are on display today in the Bardo Museum, Tunis, from their capital of Mahdiya (Fig. 7); while lifesize and larger painted plaster statues of human beings and animals were displayed in the palace of the Shii'ite Fatimid Caliph al-Mansur (946-52), which he built at al-Mansuriya, near Kairouan in Tunisia. Under Fatimid rule a variety of sculptures and statuettes of animals and birds (Hillenbrand, 2000, 435) including, in gold, "a peacock studded with precious gems, with eyes of rubies and a tail made of enamel in imitation of the colours of the living bird" (Arnold, 1965, 22, the palace version of those more everyday sculptures depicted in 1206, see Fig. 14) a gazelle in gold and similarly enriched (Irwin, 1997, 115) and a cockerel (Arnold, 1965, 22), and other figural sculptures in bronze, brass, rock crystal, glass and carved in ivory were produced. Naser-e Khosraw records the rock crystal imported from the Maghreb was etched by master craftsmen and was displayed in the Suq al-Qandil in Fustat (Thackston Jr. W. M, 1986, 53) and 22,000 amber figurines and a life-sized silver sailing boat were once in the treasury (Irwin, 1997, 115).

Sculptures and statuettes were also made from sugar for the Fatimid ruler's twice yearly feasts, as Naser-e Khosraw during his extended visit to Cairo in 1047-1048 recorded:

"They said that fifty thousand maunds of sugar (approximately 8,000 $\mathrm{Kg}$.) were appropriated for this day for the sultan's feast. For decoration on the banquet table I saw a confection like an orange tree, every branch and leaf of which had been executed in sugar, and thousands of images and statuettes in sugar" (Thackston Jr. W. M, 1986, 57; as also, Arnold, 1965, 23, citing Qalqashandi).

In $12^{\text {th }}$ c. Cairo there were sculptural automata in the hall of the Vizier al-Afdal Shahanshah (d. 1121), consisting of 8 life-sized and life-like sculptures of females wearing splendid clothes and bedecked with jewellery, 4 black and 4 white, called amber and camphor respectively, that bowed low to the Vizier on his entrance to his hall, as he crossed the threshold and then, following this ceremonial entrance, when he had sat down, they then stood upright again, forming an impressive staged entrance for the Fatimid Vizier in front of his guests (Rice, 1958). While earlier al-Mutannabi's (d. 965) Divan records a statuette of female dancing girl with long hair, a bouquet of flowers held in one hand and with one leg lifted up, that spun around and around until it came to rest on the table in front of a guest. The guest selected by the halting of this clockwork sculptural automata in front of his place, then had to drain a cup of wine and improvise some verses. This statuette was designed to irritate and mock al-Mutannabi, to distract the guests from the poet's verses, and it was ordered and employed by Karawwas, boon companion of Badr ibn ‘Ammar (Rice, 1958, citing ibn al-Muyassar’s Akhbar Misr).

A Maltese Arab engineer in the mid- $11^{\text {th }}$ c. was celebrated in poetry for building a marvelous mechanical clock, showing the movements of the celestial spheres, zodiac and eclipse which was combined with a sculpture of a female automata figure throwing balls (Luttrell, 1975, 28-9).

\section{Under the Ghaznavids and Great Seljuks}

It is recorded that the Ghaznavid Sultan Shihab ad-Dawla Mas'ud I (1031-41, 1041-50) who held a celebration in 1038, the preparations for which took three years, had four large bronze human statues that were attached to his throne and each of these statues had their arms and 
hands raised to support the weight of the solid gold crown suspended over the head of the Sultan sitting on his throne:

\begin{abstract}
"The throne itself was overlaid with covers of Rumi brocade. It had four well-filled cushions, made of silk and sewn with gold thread, laid down for the feet; a cushion for the back; and four other cushions, two for each side. A golden-plated chain hung from the ceiling of the chamber containing the dais, and came over the dais where the crown and throne were. The crown was attached to this chain, and there were four bronze figures fashioned in the shape of human beings and mounted on columns which were secured to the throne itself, so that their hands were outstretched and thus held the crown safely. In this way, the crown did not hurt the head since the chains and columns supported it, and the Sultan's cap could go underneath it" (Bosworth, 1973, 135-6, citing Abu'l-Fadl Baihaqi, Ta'rikh-i Mas’udi, Ed. Q. Ghani, 1940-53, 539-41).
\end{abstract}

The Great Seljuk sultans had in their palaces many life-size painted stucco-plaster sculptures of dancing girls and of palace attendants (See: Riefstahl, 1931, Plates, 514ff.; also, Rice, 1968, 112-121; Aslanapa, 1989, 309-311; Pancaroğlu, 2005, Exh. Cat. Nos. 39, 41) that are today in a variety of public and private collections including the Metropolitan Museum of Art in New York and in Detroit in the USA, in the Louvre, Paris, the Victoria and Albert Museum, London (Figs. 8-10) and the smaller $60 \mathrm{cms}$ figurine in the Staatliche Museen, Museum für Islamische Kunst, Berlin, Inv.-Nr. 1. 2658 (Fig. 11).

An $11^{\text {th }}$ c. gold medallion carries a low relief depiction of the seated first Great Seljuk Sultan Tughrul (1038-63) on one side and with a depiction of the reigning Caliph Abu Ja'far alQa'im (1031-75) on the other (Artuk, 1960, Lev. III, 39-40; Batur, 1994, Cat. No. 3; Turan, 1993, 389). Human figurines were made, some shaped as liquid containers (See for example, Cat. N. 14, in, Watson, 2004), and figurines of animals were also made, including, hedgehogs and horses (See for example Cat. No L.29; L.30, in, Watson, 2004). Sadid ad-Din Muhammad 'Awfi writing in the early $13^{\text {th }}$ century describes the palace of the Seljuk Prince Turanshah at Herat in the second half of the $12^{\text {th }}$ c. as, "decorated with sculpture, frescoes and of royal portraits in medallions which were located within the princely (rather than "public") quarters of the palace" (Hillenbrand, 2000, 414); and stucco figural relief sculptures survive today from the Seljuk palace at Rayy in Iran. A large stucco plaster relief panel depicting Sultan Tughrul III (1176-94) and attendants, dating from 1195, is today in the Pennsylvania Museum in the U.S.A.

\title{
Zangids, Artukids, Ayyubids, Isma'lis and elephants
}

Muhammad al-Sa'ati built a public monumental water clock automata attached to the Gate of the Hours or Jayrun Gate - Bab al-Jabiye of Damascus in 1164 (Burns, 1999, 99), during the reign of the renowned fighter for the faith, Sultan Nur ad-Din Muhamud bin Zangi (1146-74) and, at a time when Islamic values were brought to the fore through the jihad against the Latin Crusaders, this sculptural automata "consisting of a pair of brazen falcon (shaped statues) clock automata that every two hours dropped brass balls from their beaks into brass cups, from where the balls returned automatically to the interior of the device" (Newby, 1983, 35. Recorded in 1206 by Jabir ibn al-Sa'ati, who describes this clock automata which was built by his father, (Hassan-Hill, 1986, 57; Nasr, 1976, 145) (Fig. 12); two moving sculptures, a pair of metal statues of falcons, together with a statue of a human figure, as al-Jaziri records, located in a public space on a major gate of an Islamic city; and which was still in situ and working in 1326 when this sculptural automata was seen and noted by ibn Battutah, (Gibb, 1939, 66-7).

There are also the contemporary illustrations of the sculptures of figural automata known to 
have been made, from the surviving manuscript copies and their illustrations in Badi al-Zaman ibn al-Razzaz al-Jaziri's work entitled, al-Jami bayn al-ilm wa'l-a mal al-nafi fi sina'at al-hiyal, "A compendium of theory and useful practice in the mechanical arts" (Tekeli, Dosay, \& Unat, 2002); produced in 1206 in Diyarbakir for the Artukids and today in Istanbul, T.S.M., Kitaplığı, Ahmet III, 3472. (Figs. 13-15). Accurate working copies, including some over life-size statues of these late $12^{\text {th }}$ c. sculptural automata, have been made in the last decade by carefully following the engineer, Badi al-Zaman ibn al-Razzaz al-Jaziri's instructions (A large size working replica of al-Jaziri's elephant clock automata was installed in the Indian Hall of the Ibn Battutah Mall in Dubai in 2005. For the scientific contribution made by al-Jaziri and the working models which have recently been made to his designs, see, youtube ancient Islamic discoveries (Al Jaziri) parts 1-7 from the Heritage Channel, and, youtube elephant clock at www.muslim heritage.com). He also designed the superb brass doors to the Cizre Mosque, with lion head and dragons knockers today in the TIEM, Istanbul. Human figures fighting dragons are carved in relief on the exterior facade of the $13^{\text {th }}$ c. al-Khan (caravanserai) at Sinjar, Iraq.

In 1250 at the third meeting between the Isma'li assassins and King Louis IX of France (1214-70), the king was presented with a series of gifts including a chess set and a crystal elephant (Burman, 1987, 128-9), possibly indicating the continuity of the tradition of sculptures in rock crystal known from Fatimid Egypt or a Fatimid period heirloom. Further, in addition to the gift of a sculpture in rock crystal of an elephant, al-fil, the elephant was also represented in the chess pieces (al-fil, the elephant is the piece called by Christians the bishop) given to the King. If the Isma'li's were also referring through this gift of elephants to Louis IX to the Holy Koran Sura 105, Al-Fil, with its clear description of the defeat of the Christian Ethiopian army's invasion of Arabia by King Abraha in c.570, in the year of the Prophet Muhammed's birth, is today unknown, but seems, to this author at least, not at all unlikely; as likewise, the meaning behind the gift of a live elephant given by the Abbasid Caliph Harun al-Rashid (786-809) to the Holy Roman Emperor Charlemagne (c.742-814), whose envoy, after warning the Caliph over the 17 monks killed in Jerusalem in 797 by Bedouin raiders, brought back the elephant, Abulabbas, to France, the party reaching Aix-la-Chapelle on the $20^{\text {th }}$ of July, 802, and the elephant Abulabbas died in 810 (Hitti, 1991, 298; Clot, 2005, 104-5). Not that the Emperor Charlemagne or King Louis IX or their advisors would necessarily have been aware of the meaning and of the warning implicit in the gift of a live, or in the sculpture of an elephant, given to a Christian ruler, but then a diplomatic gift may carry a multiplicity of meanings, some addressed to the audience around the sender and to the Almighty, rather than to the ostensible recipient. The gift of an elephant not only reflected the might of the sender, and the demands placed upon the recipient to sustain it, as reflected in a famous story told by the great teacher Nasred-Din Hoca (Mulla):
"The King had allowed a pet elephant loose near Nasrudin's village, and it was destroying the crops. The people decided to go in a body to Timurlane (Timur) to protest. Nasrudin, because he was known to amuse the king at times, was appointed the leader of the delegation. So overawed were they by the magnificence of the Court that the group pushed Nasrudin into the audience chamber and fled. Yes, said the king, 'What do you want Nasrudin?'
About your elephant, your Majesty...' stammered the Mulla. He saw that the King was in a bad temper that morning.
'Yes - what about my elephant?'
'We, that is, I, was thinking it needed a mate'” (Shah, 1975, 159).

But also this gift reminded those who knew of what the Holy Koran, Sura 105, Al-Fil, records, 
that the mighty Christian army led by its great elephant Mahmud can, at the will of the Almighty be destroyed, by little birds, like swallows, flying across the sky and dropping clay pellets. Other sculptures of elephants are known, including: a water-clock incorporating a sculpture of an elephant which is recorded in Badi al-Zaman ibn al-Razzaz al-Jaziri's work (Tekeli, Dosay, \& Unat, 2002, Pic. 1.58) (Fig. 15) and reconstructed in Dubai in 2005, and another elephant is carved in relief in a frieze from the walls of $13^{\text {th }}$ c. Konya, being chased by a winged lion, possibly to be read as the bedecked elephant of temporal power, fleeing from the lion of faith, which is today in the Inci Minareli Medrese, Konya. These $12^{\text {th }}$ and $13^{\text {th }}$ c. sculptures of elephants in relief and in the round possibly indicate that an important sculpture of an elephant was earlier made in $8^{\text {th }}-9^{\text {th }}$ c. Bagdad, reminding of the Sura Al-Fil, as the lancer on the dome reminded of jihad. Other sculptures of elephants produced earlier include a bronze figurine of an elephant, 11 cms long, which survives from $12^{\text {th }}$ c. Khurasan (Falk, 1985, Cat. No. 256), together with $11^{\text {th }}$ c. pottery reliefs depicting animals, including an elephant, from the palace at Ghazna.

Stucco figural relief sculptures survive today, from Badr ad-Din Lulu's (1233-59) Kara Saray, Mosul, originally about 100 in number (Arnold, 1965, 24), and from $12^{\text {th }}$ c. Ayyubid Syrian palaces. There are also the photographs recording the large relief carved on the face of the 1221 Talisman Gate of Bagdad, in for example, Sarre, \& Herzfeld, 1911-12, depicting a ruler, probably the Prophet Süleyman, holding two jinn, symbolised as dragons, by their tongues held in either hand, which was blown up in 1917 during World War One. Zakariyya b. Muhammad b. Mahmud al-Kazvini (1203-83)'s Acaibu'l-Mahlukat, Marvels of Created Things, contains a chapter devoted to the descriptions of carved images of people, of jinn, of birds and of the creatures of the sea and land (TDV 1988, 316. Translated by Wüstenfeld in 1848-9) and it is evident therefore that sculptures were appreciated into the late $13^{\text {th }} \mathrm{c}$. in Iraq, and were of sufficient interest for al-Kazvini, an Islamic judge appointed by the Caliph al-Musta'sim to Wasit and Hilla, to devote an entire chapter to them.

\section{Under the Seljuk Sultanate of Rum in Anatolia}

Given the length of this tradition of Islamic figural sculpture outlined above, stretching over a period of more than half a millennia, and usually associated with Caliphs, rulers and viziers, courts, palaces and buildings in major cities, it is not particularly surprising to find that like the Zangids, Ayyubids and Artukids, the Rum Seljuk Sultans in $13^{\text {th }}$ c. Anatolia also had works of sculpture made depicting birds, animals, melek figures and people, both freestanding and in relief, (Öney, 1992, 33-68) including as fountains, as recorded for example by Jelalad-Din Rumi,

\footnotetext{
"Men have fashioned upon the highways, in caravanserais and on the banks of pools, men of stone or birds of stone, and out of their mouths the water comes and pours into a pool" (Arberry, 1977, 52).
}

Reliefs depicting humans, birds and animals, angels, as well as jinn figures - dragons and human headed lions and human headed birds - are carved on the portals of caravanserai and other buildings, including the two melek -angel figures of the recording angels (Holy Koran, Sura 13, Al-Ra'd: 11, "Each has guardian angels before and behind him, who watch him by God's command." carved on these structures to serve as a visual reminder of faith and right behaviour, as the mihrab-like niches in the inner sides of Rum Seljuk portals, as later either side of a mosque's entrance door, served to remind of the Holy Koran, Sura 2, Al-Bakarah, 115: "To God belongs the East and West. Whichever way you turn there is the face of God.".) carved in relief on the portal of Susuz Han beside the Antalya-Burdur road, and the related, but much larger pair carved in relief upon the Citadel Gate in Konya recorded by Texier in the early $19^{\text {th }}$ c. but since lost (Fig. 16), and a further pair from the walls of Konya that are today in the Inci Minareli 
Medrese Museum (Illustrated in, Işin, 2001, 52-3), Konya. There are also, astonishingly, the two human heads carved in high relief, now defaced, above the main door in the facade of the Alaed-Din Mosque of 1223 in Nidge (See for example, Ögel, 1994, 17; Karpuz, 2009, 552), as well as the lion headed downspouts taking the water from the roof of this mosque, symbolising both the Abbasid Caliphate and the Lion of Islam, Holy Koran, Sura Al-Maddath-Thir 74: 50 where the unbelievers are described as behaving like frightened asses, fleeing from the lion of Prophetic revelation. While it is recorded that the entrance gateway to the White Palace at Ak Seray (Aksaray) built by Sultan 'Izzed-Din Kaykavas I (1211-19), had on either side of it sculptures of lions that gave off a roaring sound (Bates, 1994, 259). Rum Seljuk sculptures in relief in both stucco-plaster and in stone depicting animals, birds, jinn and people, some on horseback, and sculptures in the round of lions and jinn are displayed today in the TIEM in Istanbul, in the Inci Minareli Medrese, and Karatay Medrese (stucco) in Konya and in the Museum für Islamische Kunst, Berlin. Nor is it surprising that figurines were also made of bronze, of lead and also of stucco of birds, and in fired glazed clay, like that depicting a standing state official found in Kaleiçi, Antalya in 2006 and today in the Antalya Museum (Büyükyörük-Ulutaş, 2008, Fig. 8), as also figurines in wax and glass and cast in sugar, like those made in Bagdad (Shams-i Tabriz in the $13^{\text {th }}$ c. records that in Baghdad, "He saw a candy maker who had made little birds of sugar candy", Chittick, 2004, 271); while accurate naturalistic portraits were drawn of Seljuk rulers and others, and in some instances, low relief works of sculpture including seals were then made from these portraits (Duggan, 2007); while coins were struck carrying the image of the sculpture of the Abbasid lancer on horseback (Fig. 6) (See also Falk, 1985 Cat. Nos. 530, 531, dating from the reign of Rukned-Din Süleyman Shah).

It is within this Islamic tradition of sculpture in both public places and palaces outlined here that the Rum Seljuk sculptural reliefs on the Belkis Palace-Aspendos discovered in 2007 are to be understood as, in this respect as in others, successive Rum Seljuk rulers were simply following the example first set by the Umayyad Caliphs, and which was then followed by the Abbasid Caliphs and court in Bagdad and which was in consequence also followed in other adjacent and more distant Islamic courts, of having sculptural works, carved in relief and also life-sized statues and automata in their palaces and in other prominent places for private or for public display. It is important to understand this tradition in order to place these sculptures in their proper context, including the life-sized stucco relief depiction of the naked Shirin emerging from a pool to be seen by Keyhusrev (Duggan, 2011), that covered over the Roman relief of Dionysus in the pediment of the Roman theatre converted into the Seljuk Belkis palace, dating from 1240 in the reign of Sultan Giyathsed-Din Keyhurev II (1237-45), with the main figure remaining largely intact into the $19^{\text {th }}$ c. and which was fortunately recorded by Charles Texier (2002, 266-7) before it was destroyed (Fig. 17).

\section{Under the Khwarizm Shahs and Mongols}

A late $13^{\text {th }}$ c. glazed ceramic figurine, $43 \mathrm{cms}$ high, made in Kashan, Iran, depicting a kneeling Sultan Tughrul III(?), identified by the inscription around his Abbasid court qalansuwa, or kulah, as Tughrul, which is preserved today in the Nasser D. Khalili Collection of Islamic art (Fig. 18) (Illustrated in Irwin, 1997, Fig. 23). A further example of this same type, also from Kashan but later, of the Ilkhanid Khudabende Muhammad (1304-17), today in the Emel Kolaşin Col., indicates there were collections of these portrait figurines, distinguished through their dress, the beard type, as well as from the incised identifying inscription on the Kulah, perhaps these examples come from collections of these statuettes, produced at Kashan, of series of portrait statuettes of rulers (This Ilkhanid example forms the cover of, Ö. Diler, Illhanlar İran Moğollarının Sikkeleri. 2006). An earlier, although smaller, painted, cobalt blue, black, white and lustre, glazed, $12^{\text {th }} \mathrm{c}$. Kashan figurine-vase of a turbaned ruler sitting cross-legged holding 
the cup of the world in his right hand, but lacking an identifying inscription, is on loan to the Victoria, \& Albert Museum, London, and this seems to be one of the earliest of the series of statuettes produced at Kashan from the $12^{\text {th }}$ to the early $14^{\text {th }}$ century, depicting rulers.

\section{Conclusions}

From the $7^{\text {th }}$ c. onwards idols that were made and worshipped by pagans were smashed by Muslim rulers following the example given by the Prophet of Islam when he ordered the destruction of all the idols within the Haram in Mecca in 630, such as the idol Hubal and the 360 other idols, one for each day of the year, and others such as al-Lat, al-Uzza, on Manat and elsewhere in Arabia (For descriptions of these idols see: Abu al-Mudhir Hisham ibn Muhammad ibn al-Sa'id ibn Bishr al Kalbi (d. 821-2), his, Kitab al-Asnam), yet these same Muslim rulers often had sculptures of people, birds and animals within their own palaces, some displayed in both public and private sculptural automata, and they had human and other figures carved in relief, some on the facades of the public buildings that they ordered to be constructed; such as the Abbasid Caliph al-Mansur in the $8^{\text {th }}$ c. and Ghaznavid Sultans in the $11^{\text {th }}$ and $12^{\text {th }}$ centuries, as noted above, or the Mamluke Sultan Baybars (1260-77) who smashed an idol in the Crusader citadel of Safad in 664-665/1266-1267 (Hillenbrand, 1999, 308), but whose own symbol, the lion, is carved in relief on the facades of many of the buildings he ordered constructed in Egypt and Syria; while Christian relief carvings were sometimes re-used in Islamic buildings, rather than being smashed, or put in a wall upside down, or faced inwards so the depiction was invisible, but instead were re-worked, at times re-carved to convert a Christian depiction into an Islamic one, for example, removing the cross on the orb in the hand of the archangel Gabriel and re-carving the orb to carry inscribed on the roundel, the word Allah (Fig. 19).

Consequently it seems reasonable to suggest from the above evidence, limited though it is, that from the late $7^{\text {th }}$ c. to the $14^{\text {th }}$ c., the period surveyed in this article, Muslims, rulers and people alike, had no difficulty whatsoever in discriminating between an idol, made to be worshipped and which was worshipped by idolaters, and a work of art and artifice, which was made for and was acceptable to the Muslim community and often carrying a symbolic meaning; a statue carved in relief or in the round, of a human, or of a creature, a bird, animal, fish, jinn or angel, which was made by and for the Muslim community and which was displayed in both private and public places. Some of these sculptures remained in situ for centuries. Statuettes were made, including figurines of rulers - identified by name, while figured chess pieces were handled as a matter of course. Other statuettes-figurines were produced as toys, and some statues and statuettes made by Muslims were of a far more temporary nature and were eaten. Further, the length of time that some of these works of sculpture stood, some for centuries in the case of some of the examples given above, including the statue of the lancer on horseback on top of the dome of the Caliph Abu-Ja'far al-Mansur's Green Dome-hall of audience and the 4 statues on top of the 4 domes over the 4 gates to his round city of Bagdad; as also for the sculptures of falcons and statue of a human figure on the water-clock on the Jayrun Gate of Damascus, and for the numerous relief carvings of people and creatures on the facades of public buildings, a considerable number remaining intact to the present day, if stripped of their original paintwork, while others have been defaced, beheaded or vandalised by zealots, indicates the previously widespread acknowledgement within the Muslim community of the distinction to be made between an idol and any statue or figural relief. The point was even reached in the acceptance of sculpture in the Islamic world during this period, that at times a renowned symbolic statue, such as the jihad lancer figure crowning the Green Dome in Bagdad, could not only be commented upon and copied in illuminated manuscripts, but was also copied and struck on the coinage of sultanates and emirates, and was in consequence lodged firmly in the memory of people, even after the original had been destroyed in a storm, presumably by lightning, some 
centuries earlier.

These sculptures were made, usually by Muslim craftsmen, for Caliph and Sultan, Vizier and commoner alike, and ranged in size from over life-sized sculptures to small pottery figurines and sweets, moulded into the form of humans and creatures, sold in the market, at festivals and feasts, and figurines depicting people were even imported into $9^{\text {th }} \mathrm{c}$, Bagdad from China. Statues, sculptures in the round of people, birds and animals - formed an integral part of palace and public automata; there were also carved and cast figural reliefs and figurines including chess pieces, and also, at times, low relief carvings depicting faces, people and animals which were circulated on medallions, in seal impressions and at times were recorded on the face of coins, and this rich variety of sculptural images formed a significant part of both court and of public life in the Islamic world for centuries.

Scholars today familiar with these works of Islamic sculpture, even in the absence of inscriptions on them, have no difficulty in identifying them as works of Islamic art, produced within the Islamic world and largely by Muslim craftsmen; in dating them, and in associating an individual sculptural work with a particular school, region and sometimes in the case of metalwork, a named sculptor, even if the place where the particular sculpture was found is today unknown and even though the place of production is often disputed between Sicily, Andalusia, North Africa and Egypt, or Khorasan, and western Iran or Afghanistan, or Seljuk Syria, Seljuk Anatolia or Seljuk Iran; not confusing these sculptures with the work of East Roman, Latin Christian or Chinese sculptors. For example, a series of Chinese, Christian and Islamic statues and statuettes of the same creature, a lion, produced within the same period, and placed beside each other, exhibit distinguishably different characters and reflect different styles and tastes in representation in three dimensions. It is surely evident therefore, that there was a distinct and distinguishable tradition of Islamic sculpture, with its own repertory of subjects carrying Islamic meanings-reminders, as with the lancer on horseback, the jinn figures, including: dragons, human headed birds and human headed winged lions, and the melek figures, and that, for example, in addition to regional schools, there were Umayyad, Fatimid, Abbasid, and Seljuk styles of sculpture within this tradition, and that the products of this Islamic tradition of sculpture are distinct, and are recognisably so, forming a considerable body of works in a great variety of materials and sizes, and which are individually and collectively distinguishable from other contemporary sculptural traditions, Chinese, East Roman and Latin Christian.

In consequence, during this period of 700 years, far from there being no figural sculpture produced in the Islamic world, the Islamic works of sculpture noted here far surpassed in both quantity and quality the sculptural works produced in the Latin West from the $8^{\text {th }}$ to the $11^{\text {th }}$ centuries, and they were the equal of, and at times surpassed, the contemporary works of sculpture produced in the East Roman world. 


\section{REFERENCES}

Arberry, A. J. (1977). Discourses of Rumi. New York: Samuel Weisner.

Arnold, Sir T. W. (1965). Painting in Islam, A study of the place of pictorial art in Muslim Culture. New York: Dover.

Aslanapa, O. (1989). Türk Sanatı. İstanbul: Remzi Kitabevi.

Artuk I., \& Artuk C. (1971). İstanbul Arkeolojı Müzeleri Teşhirdeki İslamı Sikkeler Kataloğu. İstanbul: Milli Egitim Basimevi, Cilt I.

Artuk, I. (1960). “Abbasiler Devrinde Sikke”. Belleten, XXIV, 93, 26-44.

Batur, E. (1994). A Rainbow Linking East and West-Coins of the Seljuks. Exh. Cat. İstanbul: Yapı Kredi Yayınları.

Batur, E. (1994). The wind blowing from Asia to Anatolia-An exhibition of Beylik period coins. Exh. Cat. İstanbul: Yapı Kredi Yayınları.

Bates, Ü. Ü. (1994). "Evliya Çelibi's comments on the Saljuqs of Rum”. Ed. R. Hillenbrand. The Art of the Saljuqs in Iran and Anatolia, 257-262. Costa Mesa, CA, Mazda.

Bosworth, C. E. (1973). The Ghaznavids their empire in Afghanistan and Eastern Iran 994-1040. Columbia University Press.

Burman, E. (1987). The Assassins. London: Crucible.

Burns, R. (1999). Monuments of Syria. London: I. B. Tauris.

Büyükyörük, F., \& Ulutaş, Ç. (2008). “Antalya Müzesi Çalışmaları 2007”. Ed. K. Dörtlük et al. ANMED 2008-6, Antalya: AKMED.

Carboni, S. (2001). Glass from Islamic Lands, The Al-Sabah Collection. London: Thames \& Hudson.

Chittick, W. C. (2004). Me and Rumi-The autobiography of Shams-i Tabriz. Albany, State University of New York.

Clot, A. (2005). Harun al-Rashid. London: Saqi.

Contadini, A., Camber, R., \& Northover, P. (2002). "Beasts that roared: the Pisa Griffon and the New York Lion”. Ed. W. Ball, \& L. Harrow, Cairo to Kabul, Afghan and Islamic Studies presented to Ralph Pinder-Wilson, 65-84, London: Melisende.

Creswell, K. A. C. (1958). A Short Account of Early Muslim Architecture. London: Penguin.

Daniel, N. (1979). The Arabs and Medieval Europe. London: Longman.

Duggan, T. M. P. (2006). "The motifs employed on Rum Seljuk $13^{\text {th }}$ century eight pointed star tiles from Antalya Province and elsewhere in Anatolia: an interpretation”. ADALYA IX, 149-219.

Duggan, T. M. P. (2007). A $13^{\text {th }}$ century profile portrait seal depicting the face of the Rum Seljuk Sultan Alaed-Din Keykubat I (1220-37) from Antalya Province - precedents and possible influence. ADALYA X, 309-349.

Duggan, T. M. P. (2009). "Diplomatic shock and awe: moving, sometimes speaking Islamic statues”. AlMasaq, Islam and the Medieval Mediterranean, 21, 3, 229 - 267. December.

Duggan, T. M. P. (2011). "An interpretation of some unpublished in situ and recorded Rum Seljuk $13^{\text {th }} \mathrm{c}$. external and internal figural relief work on the Belkis (Aspendos) Palace”. Antalya, Gephyra 8, 143-184.

Elmore, G. (1999). "The book of the fabulous Gryphon". The Journal of the Muhyiddin ibn 'Arabi Society, $X X V, 62-87$.

Ettinghausen. R., \& Graber, O. (1994). The Art and Architecture of Islam, 650-1250. Yale Univ. Press.

Falk, T. (1985). Treasures of Islam. Exh. Cat. Geneva: Phillip Wilson Pub.

Fitzgerald, E. (1945). Rubaiyat of Omar Khayyam. London.

Gibb, H. A. R. (1939). Ibn Battuta, Travels in Asia and Africa, 1325-1354. London: Routledge.

Hassan A. Y., \& Hill, D. R. (1986). Islamic Technology-An Illustrated History. Cambridge University Press.

Hattstein, M., \& Delius, P. (2000). Eds. Islam-Art and Architecture. Cologne: Könemann

Hillenbrand, R. (2000). Islamic Architecture-Form, function and meaning. Edinburgh: Edinburgh University Press. 
Hillenbrand, C. (1999). The Crusades: Islamic Perspectives. Edinburgh: Edinburgh University Press.

Hitti, P. K. (1991). History of the Arabs. London: Macmillan.

Holt, E. G. (1957). A Documentary History of Art, The Middle Ages \& the Renaissance, Vol. 1. New York: Doubleday, Princeton University Press.

Irwin, R. (1997). Islamic Art. London: Laurence King.

Issa, A. M. (1996). Painting in Islam, between prohibition and aversion. İstanbul: VISAR

Işin, E. Ed. (2001). Aladdin's Lamp, Sultan Alaeddin Keykubad and the Art of the Anatolian Seljuks. İstanbul: Yapı Kredi Yayınları.

Karpuz, H. (2009). The photograph album of Anatolian Seljuk Works. Ankara: Selçuklu Belediyesi.

Kennedy, H. (2004). The Court of the Caliphs, the rise and fall of Islam's greatest Dynasty. London: Weidenfeld, \& Nicolson.

Laborde, L. de (1839). Voyage de l'Asie Mineue, I. Paris: Firmin-Didot Freres.

Le Strange, G. (1928). Embassy to Tamerlane 1403-1406. New York, \& London: Routledge.

Lewis, B. Ed. (1994). The World of Islam-Faith-People-Culture. London: Thames \& Hudson.

Lopez, R. S., \& Raymond, I. W. (1990). Medieval Trade in the Mediterranean World. Columbia University Press.

Luttrell, A. T. (1975). "Approaches to Medieval Malta”. London: British School at Rome Occasional Papers.

The Mathnawi of Jalalud'din Rumi. Trans. R. A. Nicholson. Gibb Memorial Trust. Cambridge, Books IVI, 1982.

Mendoza, D. H. de (1982). The War in Granada. Trans. M. Shuttleworth. London: Folio Society.

Nasr, S. H. (1976). Islamic Science-An illustrated study. Westerham, UK: World of Islam Festival Publishing Co.

Newby, P. H. (1983). Saladin in his times. London: Faber, \& Faber.

Ögel, S. (1994). Anadolu’nun Selçuklu Çehresi. İstanbul: Akbank Yayınları.

Öney, G. (1992). Anadolu Selçuklu Mimari Süslemesi ve El Sanataları. Ankara: İş Bankası Kültür Yayınları.

Pancaroğlu, O. (2005) “The Seljuks of Iran and their Successors”. Ed. D. J. Roxburgh. Turks a journey of a thousand years 600-1600, 70-100. Exh. Cat. London: Royal Academy of Arts.

Rice, D. S. (1958). “A drawing of the Fatimid Period”. SOAS Bulletin, 21, 1/3, 31-9.

Rice, T. T. (1968). "Some reflections aroused by four Seljukid stucco statues”. Anatolica, II, 112-121.

Robinson, B. W. Ed. (1988). Islamic Art in the Kier Collection. London: Faber, \& Faber.

Rugiadi, M., (2010). “The Ghaznavid Marble Architectural Decoration: An Overview”. AKPIA@MIT, 1-16.

Fairchild-Ruggles, E., Ed. (2011). Islamic art and Visual Culture an anthology of sources. London: Wiley-Blackwell.

Shah, I. (1973). The Exploit of the Inccomporable Mulla Nasrudin. London: Pan Books.

Shah, I. (1975). The Pleasantries of the Incredible Mulla Nasrudin. London: Pan Books.

Sourdel, D., \& J. (1968). La civilization de L'Islam Classique. Paris: Arthaud.

Şekerci O. (1974). Islam'da Resim ve Heykelin Yeri. İstanbul: Çanakkale Seramik Fabrikaları Kültür ve Araştırma Hizmetleri No. 3.

TDV (1988). “TDV İslam Ansiklopedisi”. 1988, I cilt, Acaibu’l-Mahlukat, G. Kut, 316. İstanbul.

Tekeli S., Dosay M., \& Unat Y. (2002). El-Cami Beyne'l- 'ilm ve'l-'Amel En-Nafi' Fl Es-Sinaa'ti'l-Hiyel, Ankara: TTK.

Texier C. (2002). Küçük Asya Coğrafyası, Cilt. 3. Çev. A. Saut. Ankara: Enformasyon ve Dokümantasyon Hizmetleri Vakfi.

Thackston, Jr. W. M, (1986). Trans. Naser-e Khosraw's Book of Travels (Safernama). New York: Persian Heritage Foundation.

Turan, O. (1993). Selçuklular Tarihi ve Türk-İslam Medeniyeti. İstanbul: Boğaziçi.

Watson, O. (2004). Ceramics from Islamic Lands-Al-Sabah Collection. London: Thames, \& Hudson.

Yakutcan, A., \& Ömür, C. (1989). İslam'da Resim, Heykel ve Musiki. İzmir: Nil. 


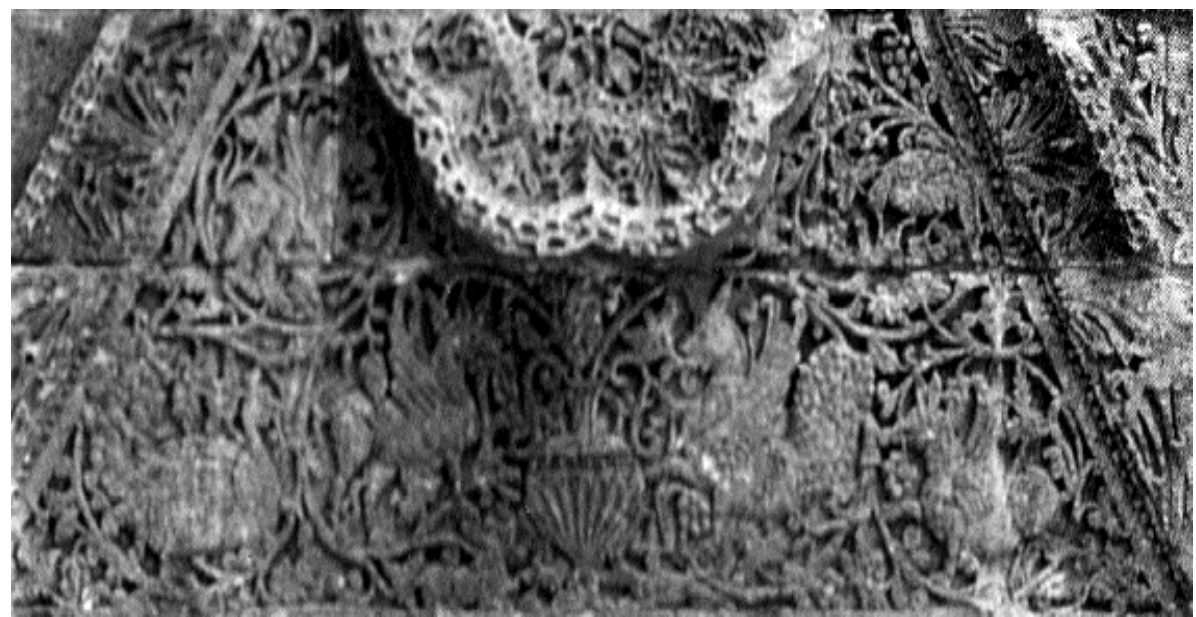

Figure 1. Relief carvings of animals from Mshatta, Jordan (from Hattstein, \& Delius, 2000).

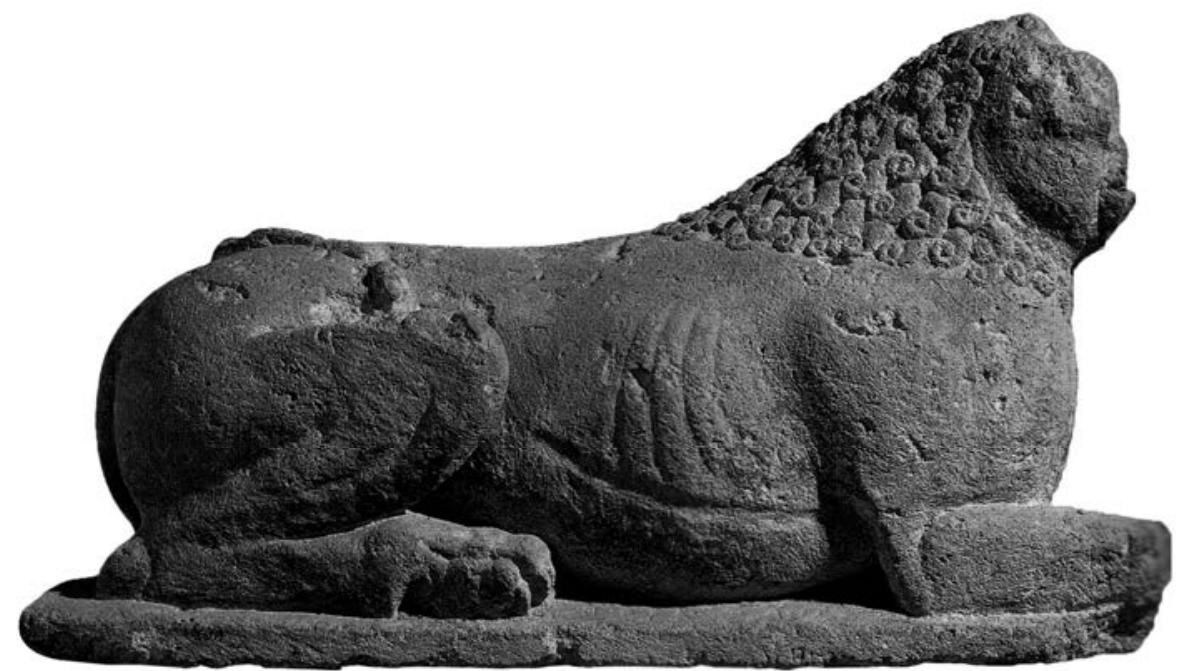

Figure 2. Sculpture of one of a pair of lions from the throne room at Mshatta, Jordan, (from Hattstein, \& Delius, 2000).

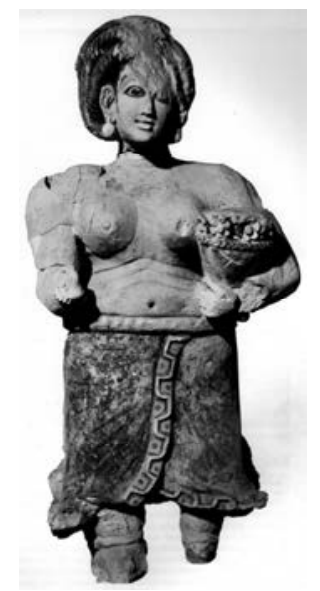

Figure 3. Painted statue of a concubine from Khirbat al-Mafjar, Palestine, (from Hattstein, \& Delius, 2000).

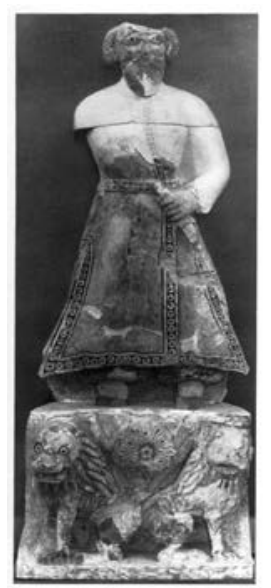

Figure 4. Stucco-plaster painted, life size standing frontal statue of the Umayyad Caliph Abu 'Abd alMalik Marwan II (744-50) (from Ettinghausen, 1994). 

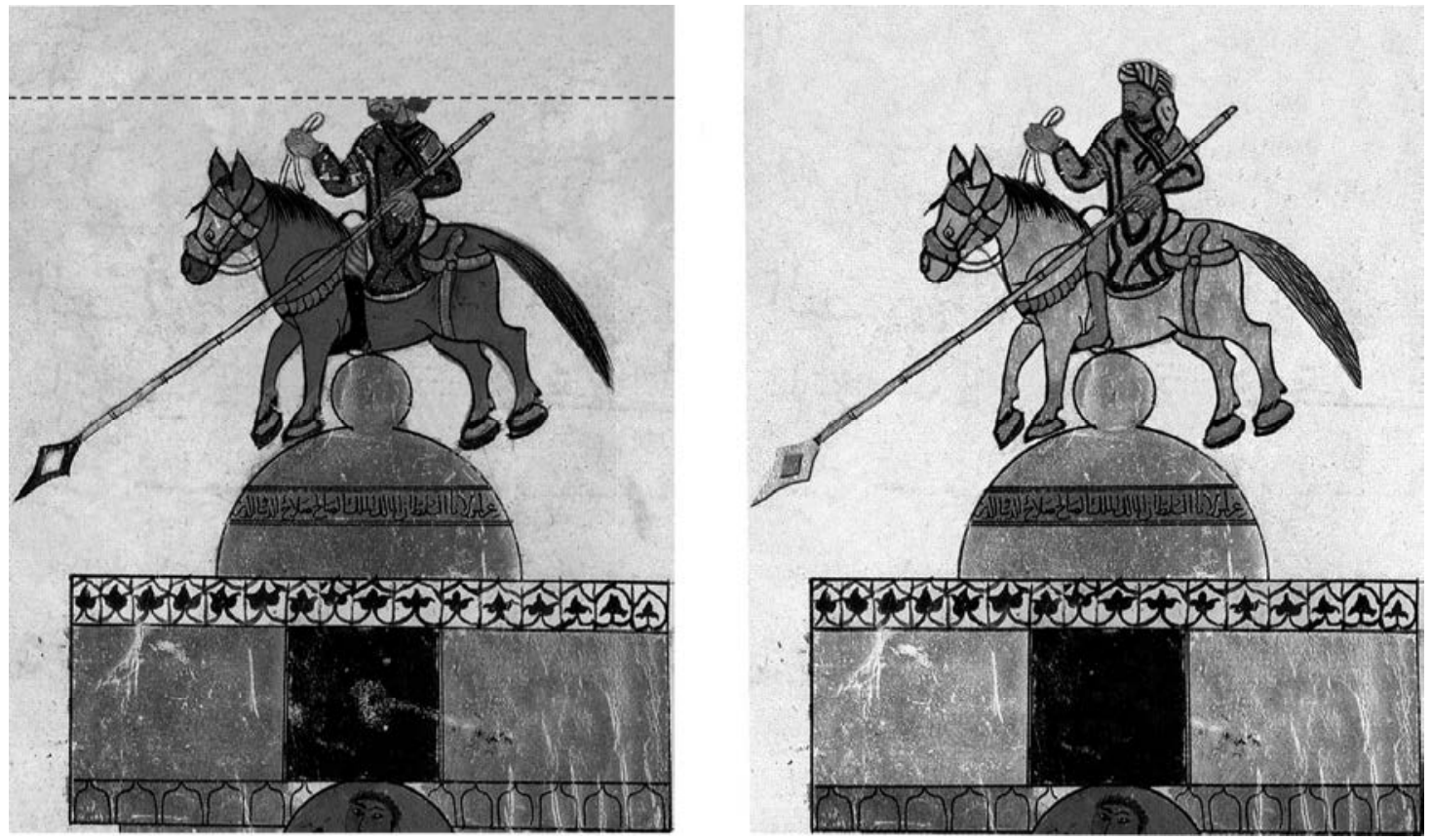

Figure 5. A dome surmounted by a lancer, probably based on that in $8^{\text {th }}$ c. Bagdad, survives in various copies of Badi al-Zaman ibn al-Razzaz al-Jaziri’s work (from Falk 1985) and a computer reconstruction of the gilded lancer on the dome of al-Mansur's Bagdad (A. Akcay).

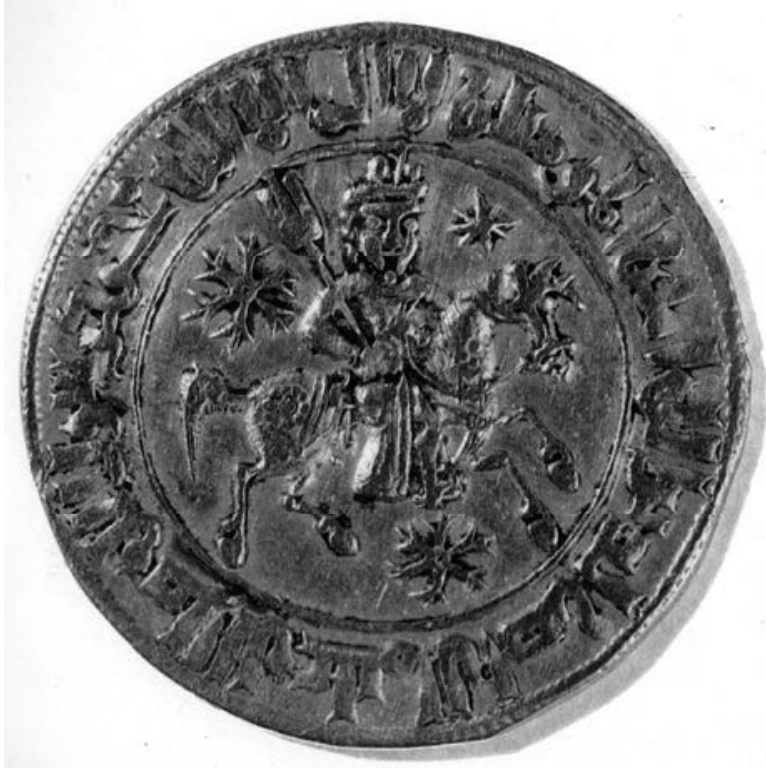

Figure 6. The Rum Seljuk Suleyman Shah's gold dinar of 1201-2 depicting the lancer figure (from E. Bartur, A rainbow linking East and West. Yapı Kredi, 1994).

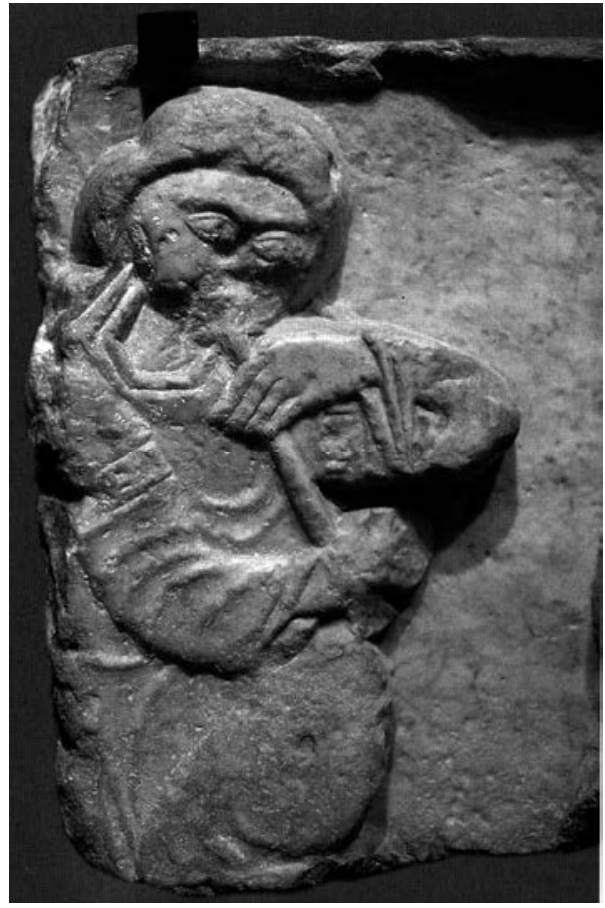

Figure 7. Fatimid relief of a female flute player, Bardo Museum, Tunis (from Hattstein, \& Delius, 2000). 


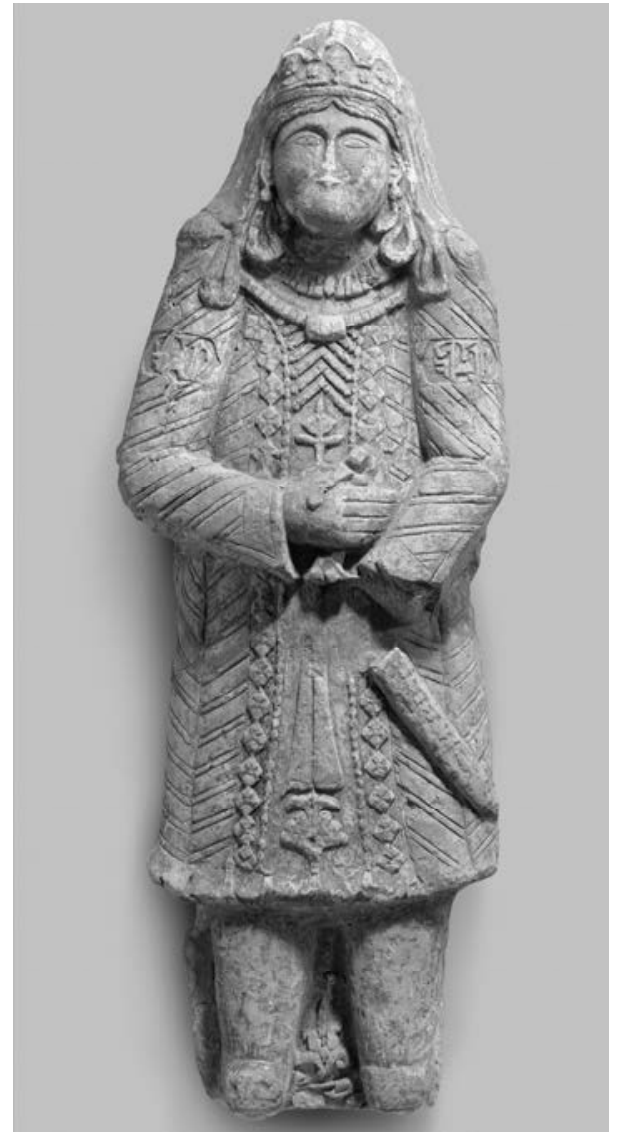

Figure 8. Life-size stucco $13^{\text {th }}$ c. Seljuk painted palace stucco figure (from D. J. Roxburgh. Ed. Turks - A Journey of a Thousand Years 600-1600. London, 2005).

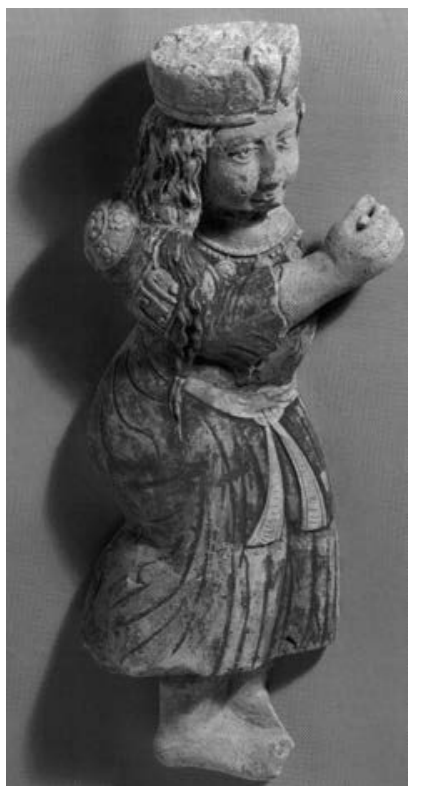

Figure 11. $12^{\text {th }}-13^{\text {th }}$ c. Seljuk painted $60 \mathrm{cms}$ tall stucco female statue from Iran (From Hattstein, \& Delius, 2000).

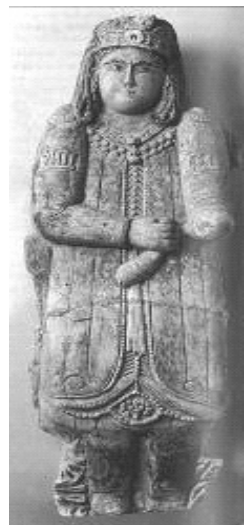

Figure 9. Near life-size $13^{\text {th }}$ c. Seljuk painted palace stucco figure (from Ettinghausen, 1994).

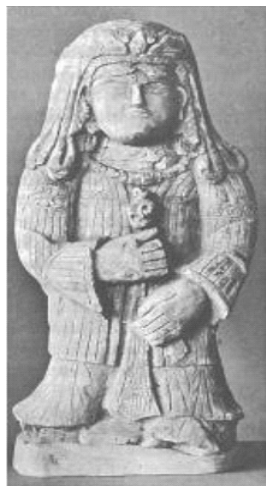

Figure 10. Near life-size Seljuk painted palace stucco figure (from O. Aslanapa, Türk Sanatı. İstanbul, 1989).

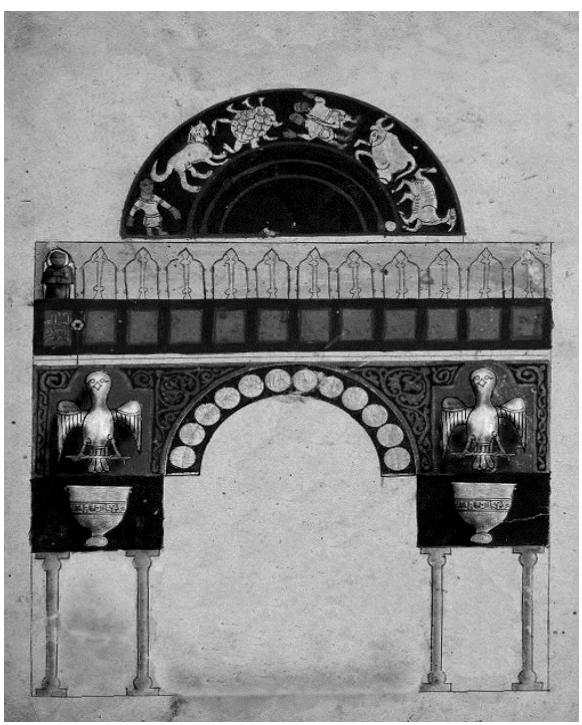

Figure 12. Sculptures of falcons, like Muhammed al Sa'ati's pair in brass on the Jayrun Gate, Damascus, recorded in Badi al-Zaman ibn al-Razzaz al-Jaziri's work (From Tekeli, Dosay, \& Unat, 2002). A computer reconstruction of the sculptures of the figure, falcons and basins on the Jayrun Gate (A. Aygün). 

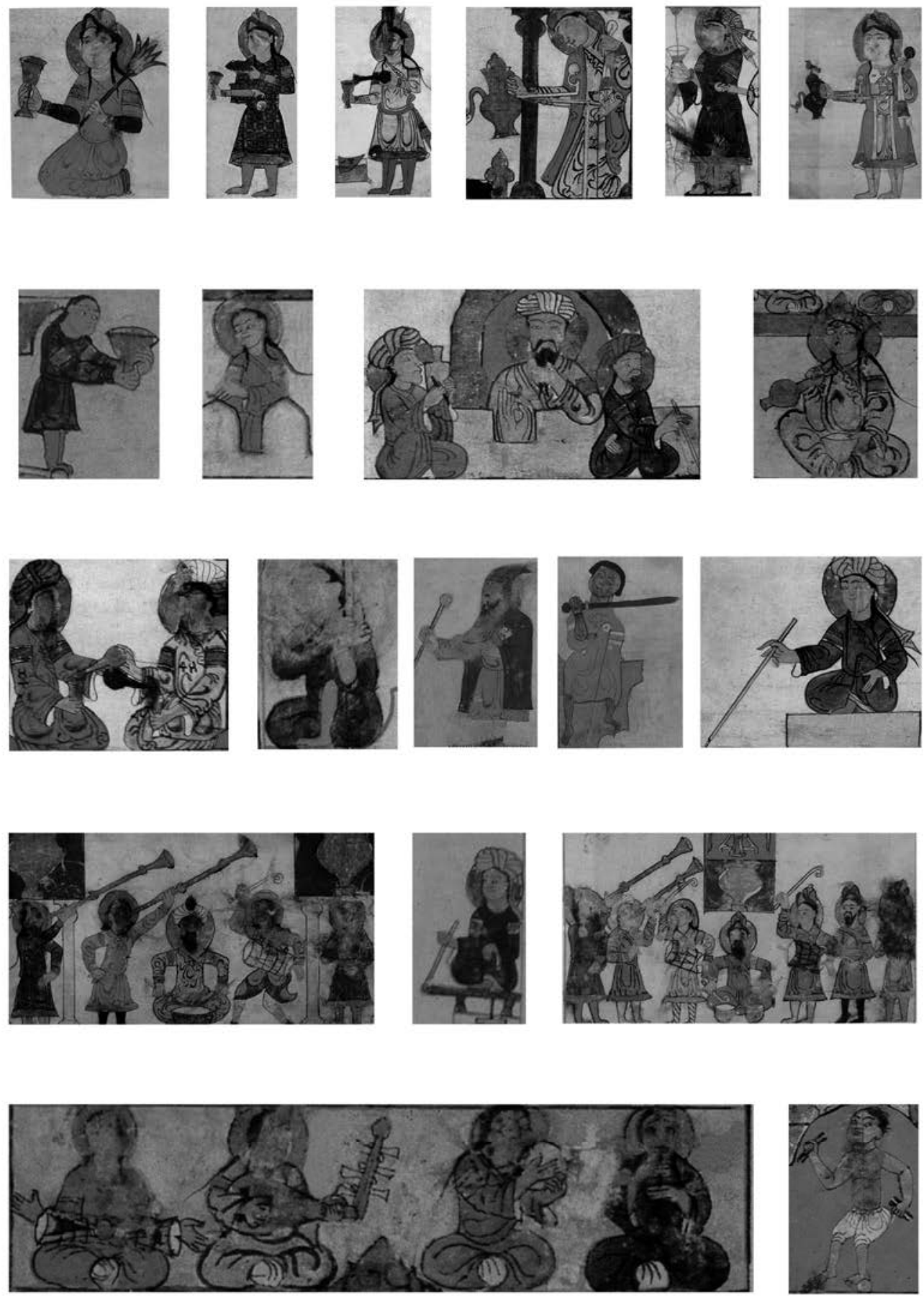

Figure 13. Examples of $12^{\text {th }}-13^{\text {th }}$ c. figural sculptures made in a variety of sizes, taken from al-Jaziri's work (From Tekeli, Dosay, \& Unat, 2002). 

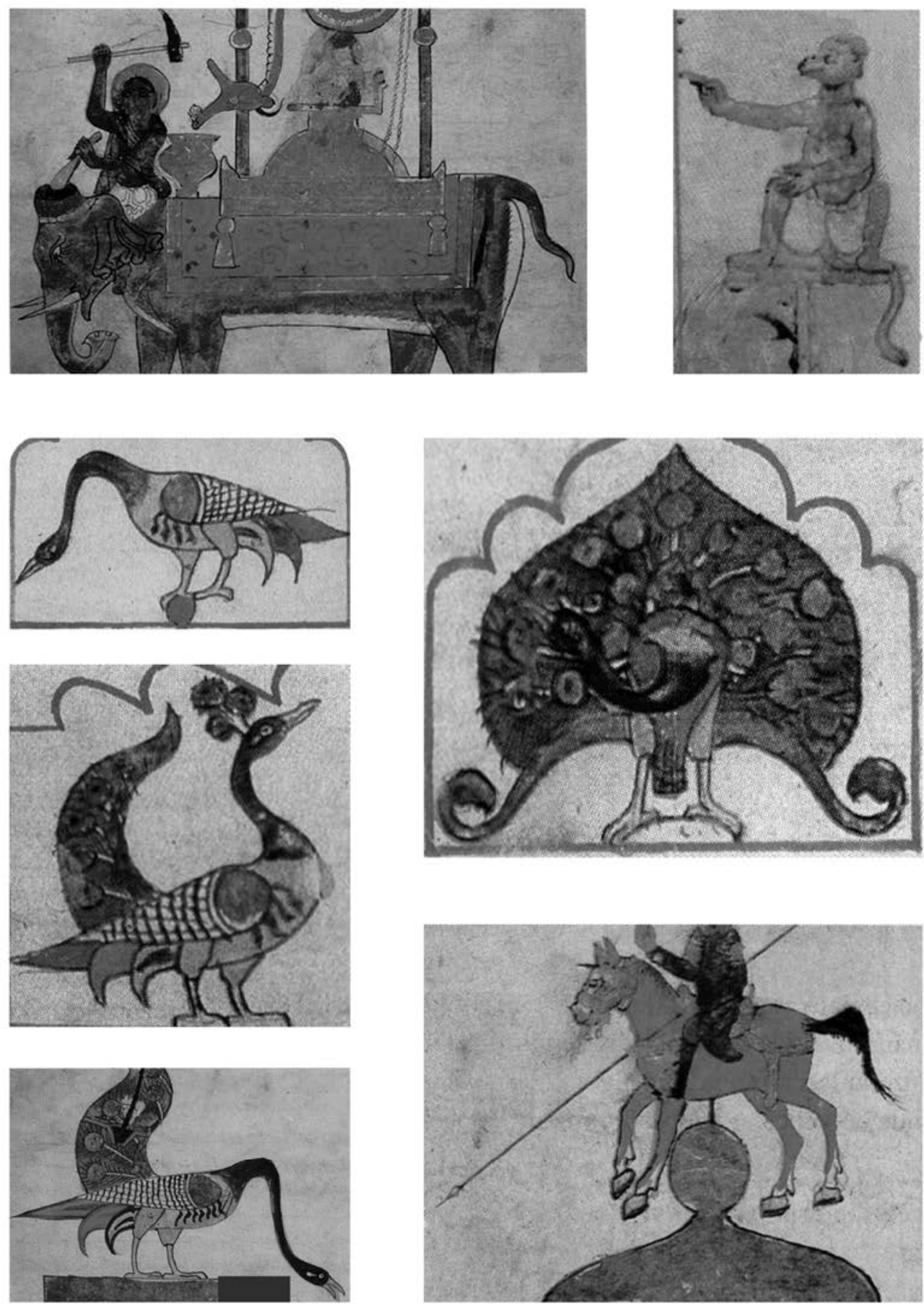

Figure 14. Examples of $12^{\text {th }}-13^{\text {th }}$ c. figural sculptures made in a variety of sizes taken from al-Jaziri's work including an elephant and mahout, a monkey and peacocks (From Tekeli, Dosay, \& Unat, 2002). 

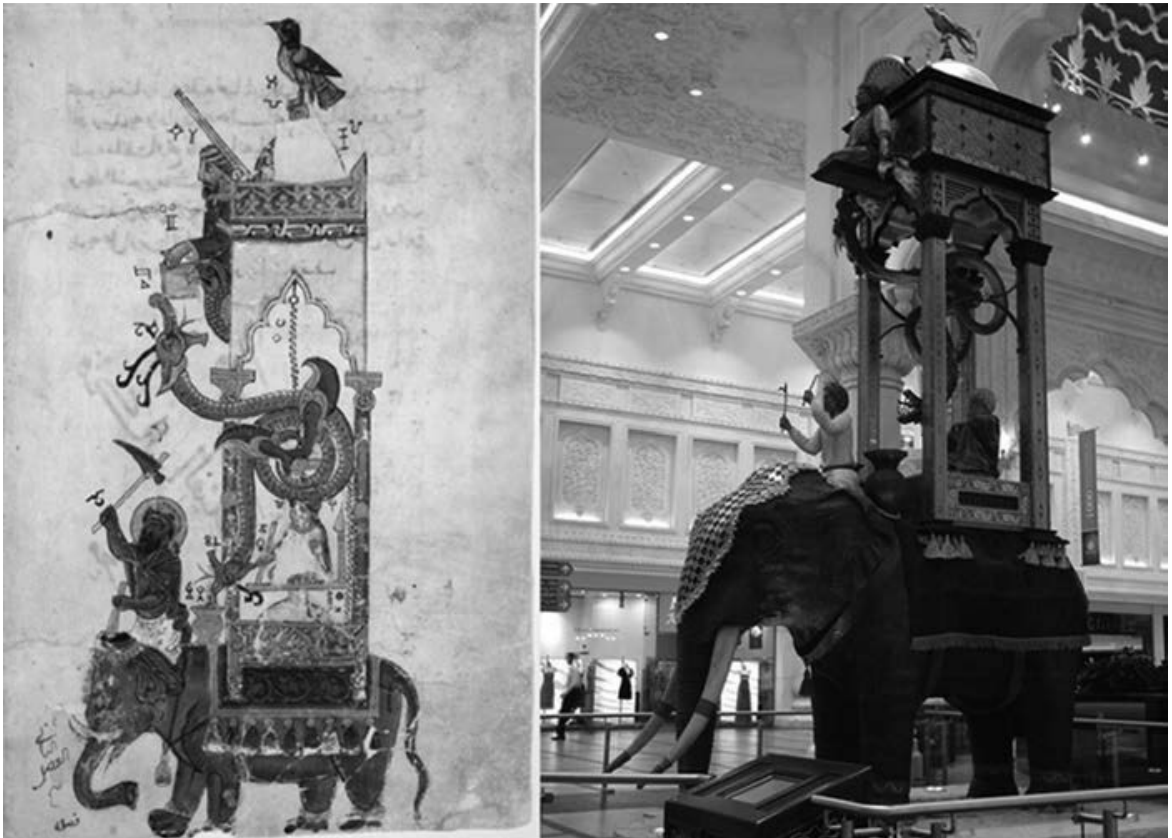

Figure 15. A copy of al-Jaziri’s elephant clock from 1315.

Reconstruction in 2005 in the Indian Hall of the Ibn Battutah Mall, Dubai.

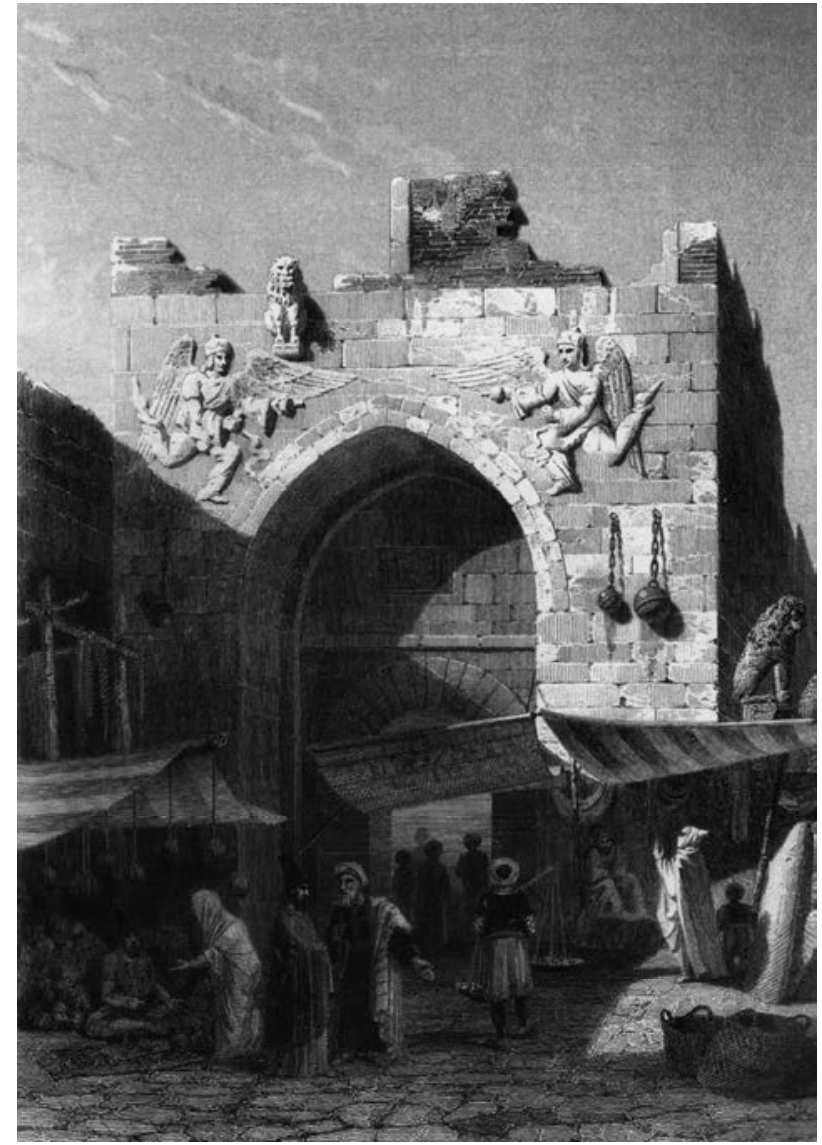

Figure 16. Engraving of the Seljuk 1221 Gate into Konya carrying large relief carved figures of two melek, drawn by C. Texier. 


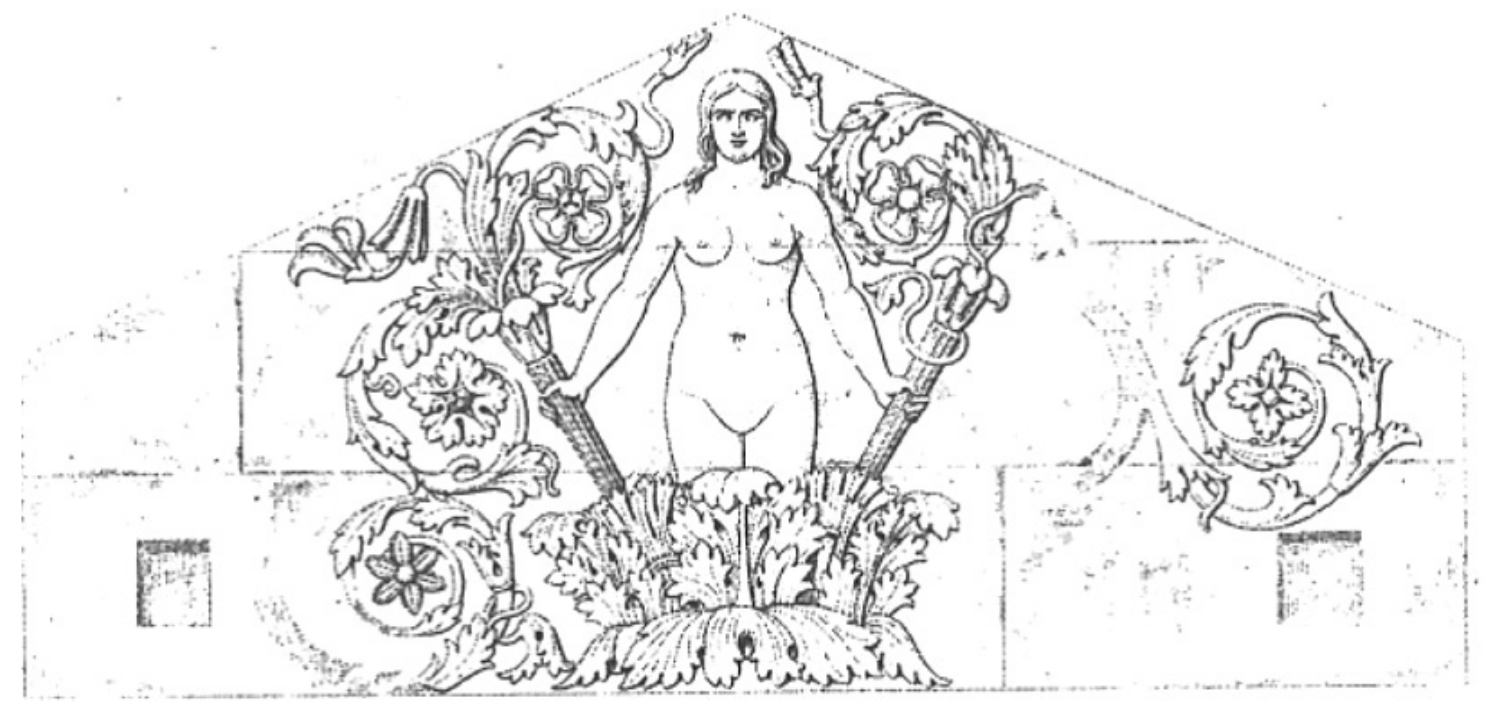

Figure 17. The remains of the Seljuk 1240 stucco relief depicting the naked Shirin bathing recorded by Texier in the Belkis Palace-Aspendos in 1837, Texier, Plate. p. 241.

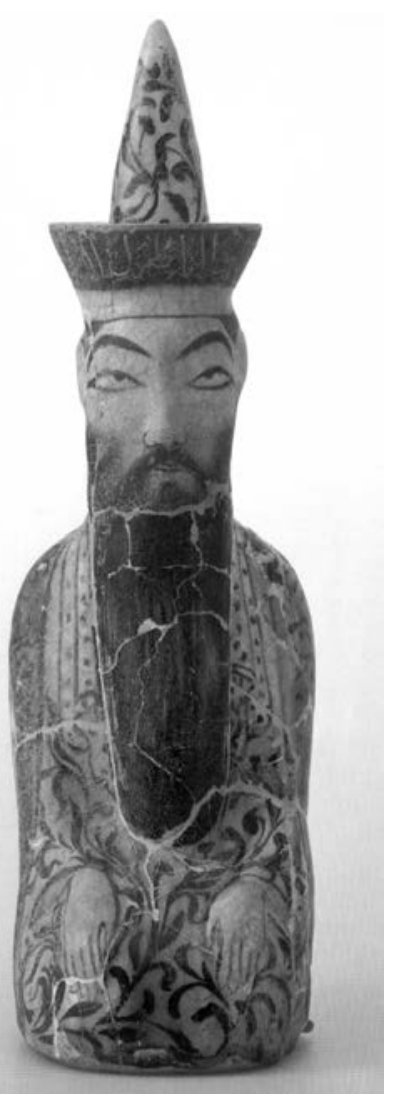

Figure 18. Late $13^{\text {th }}$ c. Kashan statuette depicting Sultan Tughrul III(?), Nasser D. Khalili Collection of Islamic art (from Irwin, 1997).

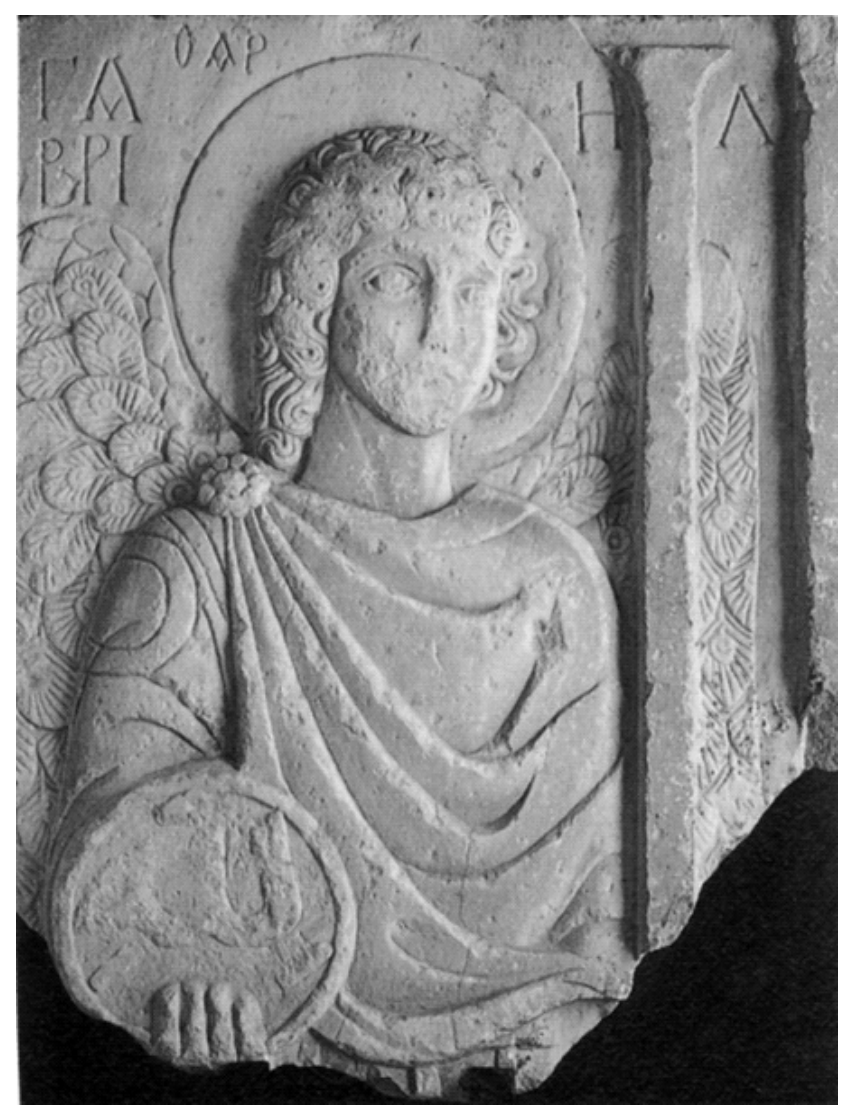

Figure 19. Re-carved and so converted and therefore fit for display on an Islamic structure, the East Roman relief of the Archangel Gabriel in Antalya Museum, Inv. No. 156. 